\title{
Article \\ Eco-Geopolymers: Physico-Mechanical Features, Radiation Absorption Properties, and Mathematical Model
}

\author{
Neslihan Doğan-Sağlamtimur 1,*D, Ahmet Bilgil ${ }^{2}$, Sefa Ertürk ${ }^{3}$, Vakkas Bozkurt ${ }^{3}$, Elif Süzgeç ${ }^{1}$, \\ Arife Gözde Akan ${ }^{1}$, Pervin Nas ${ }^{1}$, Hüseyin Çetin ${ }^{2}$ (D), Magdalena Szechyńska-Hebda ${ }^{4}$ (D) and Marek Hebda ${ }^{5}$ (D)
}

\section{check for} updates

Citation: Doğan-Sağlamtimur, N.; Bilgil, A.; Ertürk, S.; Bozkurt, V.; Süzgeç, E.; Akan, A.G.; Nas, P.; Çetin, H.; Szechyńska-Hebda, M.; Hebda, M. Eco-Geopolymers:

Physico-Mechanical Features,

Radiation Absorption Properties, and Mathematical Model. Polymers 2022, 14, 262. https://doi.org/10.3390/ polym14020262

Academic Editor: Yu-Hsun Nien

Received: 30 November 2021

Accepted: 4 January 2022

Published: 9 January 2022

Publisher's Note: MDPI stays neutral with regard to jurisdictional claims in published maps and institutional affiliations.

Copyright: (C) 2022 by the authors. Licensee MDPI, Basel, Switzerland. This article is an open access article distributed under the terms and conditions of the Creative Commons Attribution (CC BY) license (https:// creativecommons.org/licenses/by/ $4.0 /)$.
1 Department of Environmental Engineering, Niğde Ömer Halisdemir University, Nigde 51240, Turkey; elfszgc591@gmail.com (E.S.); g.akan96@gmail.com (A.G.A.); nas_pervin01@hotmail.com (P.N.)

2 Department of Civil Engineering, Niğde Ömer Halisdemir University, Nigde 51240, Turkey; abilgil@ohu.edu.tr (A.B.); hcetin@ohu.edu.tr (H.Ç.)

3 Department of Physics, Niğde Ömer Halisdemir University, Nigde 51240, Turkey; sefaerturk@gmail.com (S.E.); vakkasbozkurt@ohu.edu.tr (V.B.)

4 The Plant Breeding and Acclimatization Institute-National Research Institute, Radzików, 05-870 Błonie, Poland; szechynska@wp.pl

5 Faculty of Materials Engineering and Physics, Cracow University of Technology, Warszawska 24, 31-155 Krakow, Poland; marek.hebda@pk.edu.pl

* Correspondence: neslihandogansaglamtimur@gmail.com or nds@ohu.edu.tr

\begin{abstract}
Waste ashes and radiation are hazardous environmental and health factors; thus, a lot of attention is paid to their reduction. We present eco-geopolymer building materials (GPBMs) based on the class F fly ashes (FFAs) from thermal power plants (TPPs) and their implementation as a barrier against radioactive radiation. Different methods of production, ratios of FFA to alkali activator, and temperatures of curing were tested. Small spherical particles and higher content of $\mathrm{SiO}_{2}$ resulted in developed surface area and higher reactivity of Isken TPP FFA than Catalagzi TPP FFA. Lower activator concentration (10\% vs. $20 \%$ ) and curing temperature $\left(70 \mathrm{vs.} 100{ }^{\circ} \mathrm{C}\right)$ caused an increase in GPBM compressive strength; the highest value was measured as 93.3 MPa. The highest RA was measured for GPBMs, provided alkali activator ratio $\left(\mathrm{Na}_{2} \mathrm{SiO}_{3} / \mathrm{NaOH}\right)$ was $>2$ and its concentration was $20 \%$. The mathematical model developed in this study proved FFA quantity, and thus GPBM mechanical properties, as key factors influencing RA. In the light of these results, the lightweight GPBMs can be excellent materials for the construction sector dedicated to immobilization, storage, and disposal for radionuclides or barriers against radiation; however, multiple steps of their production require careful optimization.
\end{abstract}

Keywords: environment; fly ash; geopolymer; building material; radiation absorption; waste reuse

\section{Introduction}

The demand for building materials is increasing every day; currently, the global consumption of concrete is ranked second after water. The production of ordinary Portland cement (OPC) consumes both energy and natural resources. As stated in the International Energy Agency's Greenhouse Gas R\&D Programme, cement production releases approximately $50 \%$ of total $\mathrm{CO}_{2}$ emission ( $0.81 \mathrm{~kg} \mathrm{CO} 2$ per $\mathrm{kg}$ cement) [1].

Geopolymers have been studied extensively as an alternative building material that is environmentally friendly and serves as part of sustainable development [2-4]. Comparing the OPC, the main advantage of a geopolymer is outstanding mechanical properties and durability [5-8], chemical resistance [3], and thermal resistance [9]. Moreover, geopolymer production is cost-effective and has a $60-80 \%$ lower carbon footprint and resource consumption. Existing studies usually focus on ecological aspects of geopolymers, including synthesis of geopolymers from waste and disposal of radioactive waste in the geopolymer matrix [9-11]. Geopolymers are also novel in the context of removing organic pollutants from water and air to protect and improve the environment $[12,13]$. 
Davidovits introduced the term "geopolymers" to assign a new class of aluminosilicate materials with a three-dimensional structure, and he developed alkali activated fly ash (FA)-based geopolymers [14]. FA is an industrial solid waste released from coal-fired power plants. FA is produced from the burning of pulverized coal in a coal-fired boiler and is usually collected from the flue gas by electrostatic precipitators or mechanical collection devices such as cyclones. When pulverized coal is combusted in a dry-bottom boiler, about $80 \%$ of the ash leaves the furnace as FA in the flue gas. When pulverized coal is combusted in a wet-bottom (or slag-tap) furnace, $50 \%$ of the ash is retained in the furnace, with the other $50 \%$ being entrained in the flue gas. During this process, some parts of coal cannot be ignited or burned; thus, FA includes combustible material. FA has a chemical composition that is difficult to control, and the quality of FA depends on the type of coal and efficiency of the power plant. FA usually comprises fine particles and a high amount of amorphous silica and alumina; therefore, it is used as a raw material to produce geopolymers $[15,16]$. High strength geopolymers are produced based on a class F FA $[17,18]$. To obtain alumina and silica precursors, FA should be mixed with an alkali solution $[19,20]$. Common alkali activators are sodium hydroxide $(\mathrm{NaOH})$, potassium hydroxide $(\mathrm{KOH})$, or their combination, used together with sodium silicate $\left(\mathrm{Na}_{2} \mathrm{SiO}_{3}\right)$ or potassium silicate $\left(\mathrm{K}_{2} \mathrm{SiO}_{3}\right)$ [21].

The final properties of a geopolymer depend on many variables concerning raw materials, i.e., (1) mineralogical and chemical composition, (2) structural properties, and (3) physical properties. Similarly, many factors affect the properties of the geopolymer during the production process; (4) ratio of raw materials, (5) duration of mixing and temperature of the mixture, (6) rheology modifiers, accelerators, or retarders influencing the setting time, and (7) curing time. As the design and the appropriate selection of ingredients in laboratory conditions are costly and time-consuming, to achieve the mechanical properties supporting the usage of FA in the building industry, research using data-driven methods, artificial intelligence, machine learning methods, and precise mathematical modeling should be developed [21].

Much research has been performed to assess geopolymer materials as a matrix for immobilization, storage, and disposal of radionuclides or as barriers against radiation. Different types of harmful radiation, i.e., neutron, $\mathrm{X}$-ray, and gamma-ray can penetrate the conventional cement walls and roofs and easily escape from accelerators, hospitals, and nuclear power plants. If required, heavy concrete (approximately 1.5 times heavier and denser than OPC, with density $2900-6000 \mathrm{~kg} \mathrm{~m}^{-3}$ ) is used for wall and roof barriers [22]; however, interest in the production of the geopolymer barriers that absorb radiation more efficiently than concrete has gradually increased [11,23-26]. A number of studies investigating geopolymer barriers focus on their behavior in the context of radioactive element leaching (e.g., cesium (Cs), strontium (Sr)). In this case, the selection of a precursor material and appropriate activator has a key impact due to immobilization occurring via ion exchange, physical adsorption, and encapsulation by the gel matrix [11]. The FA-based geopolymer showed an excellent immobilization of $\mathrm{Cs}$ and $\mathrm{Sr}$, while slag-blended geopolymers and OPC were less suitable [27]. Sodium-based geopolymers had a better selectivity for $\mathrm{Cs}$ at a molar ratio $\mathrm{Cs} / \mathrm{Al}=0.3$ and $\mathrm{Na} / \mathrm{Al}$ ratio range from 0.7 to 1.3. Sr leaching was greater in acidic conditions than in deionized water [26]. Radioactive borate waste was solidified using metakaolin activated with $\mathrm{KOH}$ [28]. Low-Ca geopolymers had a unique ability to immobilize nuclide ions, due to the cross-linked network [11]. In the case of the geopolymer barrier, the effect of barite in FA-based geopolymer was also investigated [22] The study showed that the attenuation coefficient was directly related to the type of raw material, but there was no significant effect of change in its aggregation on the radiation absorption (RA) properties of the geopolymer. Furthermore, studies were performed to design a shielding material based on a geopolymer material with $15 \%$ barium sulphate [29] and heavyweight aggregates [30,31]. Due to the excellent immobilization of low- and intermedium-level radionuclide waste, geopolymers were approved for a waste package for sludge/resin mixture by the Slovak and Czech Nuclear Regulatory Authorities (i.e., 
the SIAL ${ }^{\circledR}$ matrix). Approximately $29.6 \mathrm{~m}^{3}$ (38.15 $\mathrm{t}$ ) of waste with total activity around $4.94 \times 10^{12} \mathrm{~Bq}$ were immobilized between 2003 and 2010 [26,32].

In most countries, the vast majority of FA is stored in authorized warehouse sites. The limited possibilities of the usage of class F fly ash (FFA) necessitate efforts to solve the environmental and economic problems with waste. In terms of the number of power plants, Turkey ranks near the top 15 in the world [33]. According to Özkan et al. [34], the annual amount of FA exceeded $50 \mathrm{Mt}$ in 2020. In this study, eco-geopolymer building materials (GPBMs) were produced based on FFAs from Catalagzi Thermal Power Plant (TPP) (Zonguldak, Turkey) and Isken Sugozu TPP (Adana, Turkey) as raw materials and $\mathrm{NaOH}$ and / or $\mathrm{Na}_{2} \mathrm{SiO}_{3}$ as alkali activators. The RA percentage of GPBMs was measured using a Cs-137 radiation source. In addition, mathematical model was developed to predict RA instead of conducting time-consuming and costly experiments. The experimental data were fitted to a polynomial function using the least-squares method. The polynomial functions were maximized under the substance constraints to find optimum mixtures and achieve the maximum RA (\%). The study intended to reduce the environmental problem, contribute to a circular economy and zero waste principles by means of waste FFA reuse as a raw material, and reduce carbon footprint and global warming by using cementless geopolymer technology and GPBMs with a high capacity of RA (comparing to conventional building materials). Therefore, following the definition of "eco-materials" in the Eco-products Directory 2010, geopolymers developed in this study refer to "materials (or material technologies) that possess excellent characteristics with good performance, which can be manufactured, used, and recycled or disposed of, while having only a low impact on the environment as well as being kind to humans". With the above in mind, we described developed materials as eco-geopolymer.

\section{Materials and Methods}

\subsection{Raw Materials Characteristic}

Morphology of FFAs supplied from Catalagzi and Isken TPPs was determined with a Zeiss/EVO 40 scanning electron microscope (Jena, Germany). Sieve analysis (UTEST UGT0411, Ankara, Turkey) of the FFAs was performed according to the Turkish Standards-European Norm (TS EN) 933-10 [35]. The chemical composition of the FFAs was analyzed with an X-ray fluorescence (XRF) spectrometer (Zetium-X, PANalytical. B.V, Almelo, Netherlands), equipped with an ultra-high performance X-ray tube with a $2.4 \mathrm{~kW}$ rhodium anode. To assess the amount of residual combustible material, $20 \mathrm{~g}$ of FFA was oven-dried at $105{ }^{\circ} \mathrm{C}$, and the sample was weighed (x), kept $2 \mathrm{~h}$ in a muffle furnace (Kaleo RS150, Kutahya, Turkey) at $750{ }^{\circ} \mathrm{C}$, then cooled to room temperature and weighed (y). Loss on ignition (LOI) was calculated by the formula: $[(x-y) / x] \times 100$. The specific surface area; micro-, meso-, and macro-pore size; as well as distribution of the pore size were determined as a function of relative pressure with the Brunauer-Emmett-Teller (BET) method using a Quantachrome/NOVAtouch LX4 (Anton Paar, Graz, Austria) physical sorption analyzer. The sample degassing temperature was $300{ }^{\circ} \mathrm{C}$, rate $20^{\circ} \mathrm{C} \mathrm{min}-1$, soak time $180 \mathrm{~min}$, and relative pressure (p/p0) in the range from 0.021 to 0.994 for 44 measuring points. The results were analyzed using the AsiQwin software (Anton Paar, Graz, Austria).

\subsection{GPBM Assessment Methods}

GPBMs were produced based on FFAs and the RILEM Cembureau standard sand [36]. Alkali activators consisted of $12 \mathrm{M} \mathrm{NaOH}\left(97 \%\right.$ purity) and $\mathrm{Na}_{2} \mathrm{SiO}_{3}\left(29.4 \% \mathrm{SiO}_{2}, 14.7 \%\right.$ $\mathrm{Na}_{2} \mathrm{O}$, and $55.9 \% \mathrm{H}_{2} \mathrm{O}$, by mass). Alkali activator $\mathrm{NaOH}$ was used at a ratio of $10 \%, 15 \%$, $25 \%$ alkaline activator to FFA (by weight); or $\mathrm{NaOH} / \mathrm{Na}_{2} \mathrm{SiO}_{3}$ solutions (1:0, 1:1, 1:1.5, 1:2, and $1: 2.5$ ) were used at a ratio of $10 \%$ and $20 \%$ alkaline activator to FFA (by weight) (Table 1 ). The samples were selected according to their mechanical properties for further studies. 
Table 1. GPBM samples produced based on the Catalagzi and Isken TPP FFAs, with or without the RILEM Cembureau standard sand, activated with the alkali activators $\left(\mathrm{NaOH}\right.$ and $/$ or $\left.\mathrm{Na}_{2} \mathrm{SiO}_{3}\right)$ in different proportions, i.e., $\mathrm{NaOH}$ used at a ratio of $10 \%, 15 \%, 25 \%$ alkaline activator to FFA (by weight) and $\mathrm{NaOH} / \mathrm{Na}_{2} \mathrm{SiO}_{3}$ solutions (1:0, 1:1, 1:1.5, 1:2, and 1:2.5) used at ratio of $10 \%$ and $20 \%$ alkaline activator to FFA (by weight).

\begin{tabular}{|c|c|c|c|c|}
\hline FFA Type & $\begin{array}{c}\mathrm{NaOH} \text { to } \\
\mathrm{Na}_{2} \mathrm{SiO}_{3} \text { Ratio }\end{array}$ & Sand & $\begin{array}{c}\text { Alkaline } \\
\text { Solution to FFA } \\
\text { (\% by Weight) }\end{array}$ & $\begin{array}{c}\text { Curing } \\
\text { Temperature }\end{array}$ \\
\hline $\begin{array}{c}\text { Isken TPP, } \\
\text { Catalagzi TPP }\end{array}$ & $\begin{array}{c}1: 0 \\
1: 0 \\
1: 1 \\
1: 1 \\
1: 1.5 \\
1: 1.5 \\
1: 2 \\
1: 2 \\
1: 2.5 \\
1: 2.5\end{array}$ & $\begin{array}{l}+ \\
- \\
+ \\
- \\
+ \\
- \\
+ \\
- \\
+ \\
-\end{array}$ & $\begin{array}{c}10 \% \\
15 \%, 25 \% \\
10 \% \\
10 \% \\
10 \%, 20 \% \\
10 \%, 20 \% \\
10 \%, 20 \% \\
10 \%, 20 \% \\
20 \% \\
20 \%\end{array}$ & $70^{\circ} \mathrm{C}, 100^{\circ} \mathrm{C}$ \\
\hline
\end{tabular}

To produce GPBMs based on FFA (without the RILEM Cembureau standard sand), "separate" and "normal" mixing methods were tested. For "separate" mixing, FFA was mixed with $\mathrm{NaOH}$ for 10 min to enable the leaching of ions. Although, the paste was relatively viscous, subsequently added $\mathrm{Na}_{2} \mathrm{SiO}_{3}$ solution required short mixing to obtain a homogeneous paste. For "normal" mixing, $\mathrm{FFA}, \mathrm{NaOH}$, and $\mathrm{Na}_{2} \mathrm{SiO}_{3}$ were mixed for 1 min [14]. To produce GPBMs based on FFA and the RILEM Cembureau standard sand, all ingredients were mixed approximately for $3 \mathrm{~min}$. Paste workability was determined in terms of flow characteristics according to the ASTM C1437-15 [37]. The pastes were poured into a mold with dimensions of $4 \times 4 \times 16 \mathrm{~cm}$. GPBMs were cured $24 \mathrm{~h}$ at 70 and $100{ }^{\circ} \mathrm{C}$. After completing the thermal curing, the samples were demolded and kept at room temperature until the testing time at 7,28 , and 90 days.

GPBM density was calculated according to the following equation (Equation (1))

$$
\gamma=\mathrm{m}_{\mathrm{ad}} / \mathrm{V}_{\mathrm{g}}\left(\mathrm{g} / \mathrm{cm}^{3}\right),
$$

where $m_{a d}$ is the air-dried mass, and $V_{g}$ is the gross volume of the samples.

The water absorption of the samples was analyzed according to TS EN 772-3 [38]. Water absorption by mass (Am) and by volume (Aw) was calculated according to the following equations (Equations (2) and (3))

$$
A m=\left(m_{s a}-m_{d}\right) / m_{d} \cdots 100(\%),
$$

where $m_{s a}$ is the saturated mass and $m_{d}$ is the dried mass

$$
\mathrm{Aw}=\left(\mathrm{m}_{\mathrm{sa}}-\mathrm{m}_{\mathrm{d}}\right) /\left(\mathrm{m}_{\mathrm{sa}}-\mathrm{m}_{\mathrm{s}}\right) \cdots 100(\%),
$$

where $\mathrm{m}_{\mathrm{s}}$ is the sample mass (according to the Archimedes principle).

The porosity was a measure of "empty" spaces in a material and was expressed as a volume of voids relatively to the total volume (apparent porosity).

The flexural strength test was performed according to the ASTM C348-14 [39] and the compressive strength test according to the ASTM C349-14 [40].

RA measurements were performed using a Geiger-Müller counter and Cs-137, a source of gamma rays of high energy. The scheme of the experimental setup is given in Figure 1a. A lead radiation shield (LRS) cage with a lattice system consisting of nested lead plates (4 mm thick) was designed and applied to avoid uncontrolled radiation (Figure $1 \mathrm{~b}$ ). 
(a)

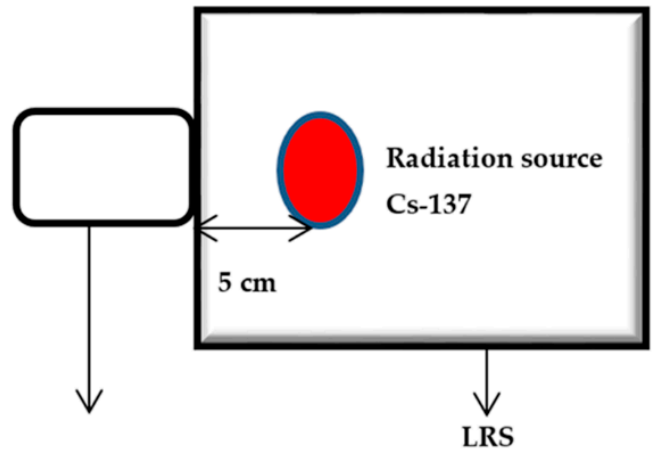

Gamma-Scout

Geiger Muller Counter

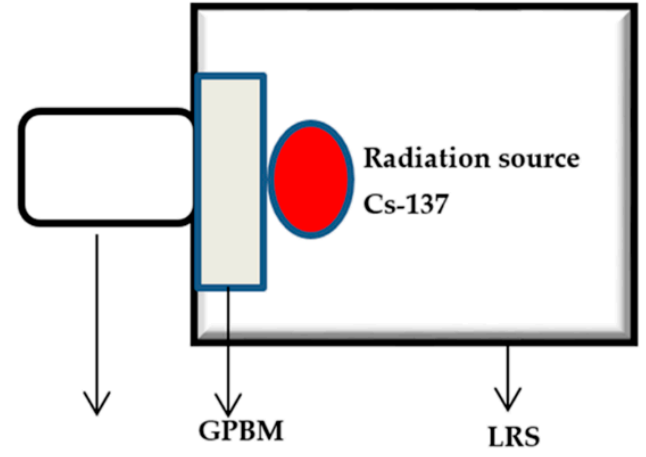

Gamma-Scout

Geiger Muller Counter

(b)
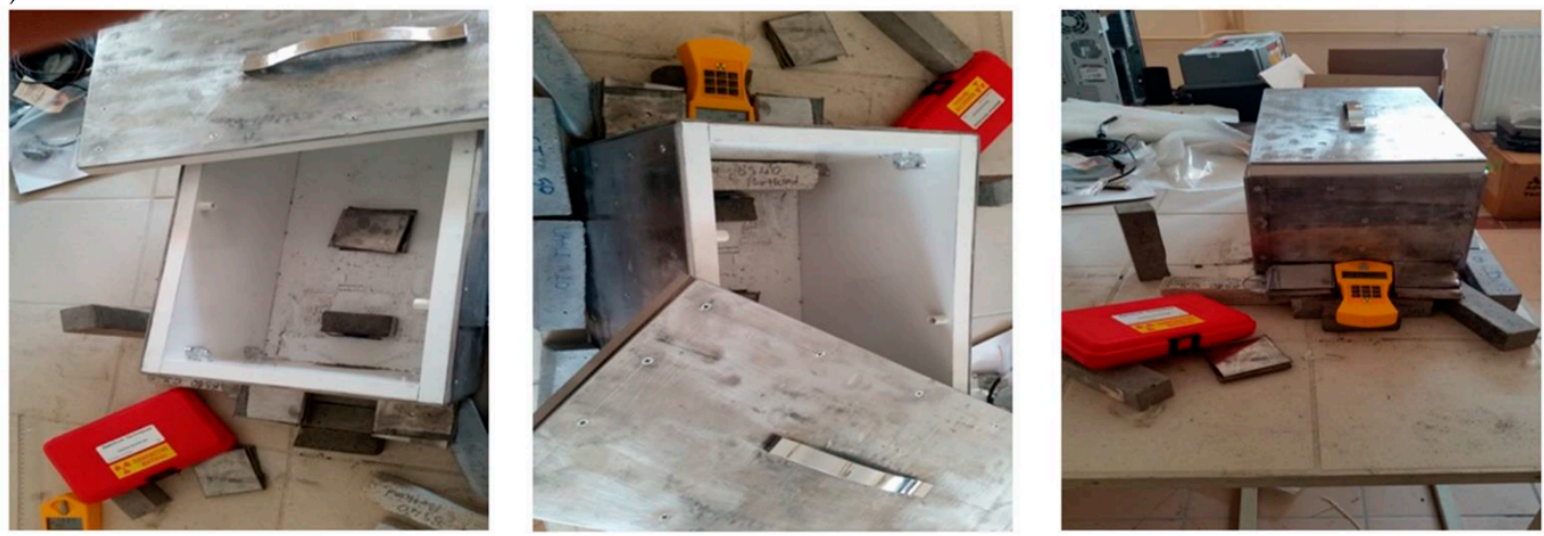

Figure 1. Experimental setup: (a) scheme of RA measurement and (b) a newly designed LRS cage.

In the first step, gamma rays emitted from the radioactive source were measured in the absence of GPBMs (Figure 1a). In the second step, GPBM was placed between radioactive source and Geiger-Müller counter (Figure 1a). In both steps, data were recorded for one hour. The radiation absorbed by the sample was calculated as a ratio from both measurements.

In accordance with TS EN 12390-3 [41], all experiments were performed with at least three repetitions. The repetition $(n)$ was defined as an individual sample at given conditions. The repeatability of the result of measurement was below $9 \%$.

\section{Results and Discussion}

\subsection{The Properties of Raw Materials}

FFAs are considered as important raw materials for geopolymer production; however, their reactivity depends on chemical and physical properties. To prove the potential of the Catalagzi TPP FFA and the Isken TPP FFA for utilization in the geopolymerization process, the chemical composition was analyzed (Table 2). The amounts of $\mathrm{SiO}_{2}$ and $\mathrm{Al}_{2} \mathrm{O}_{3}$, the most important determinants of the geopolymerization process, were relatively high in both the Catalagzi TPP FFA and the Isken TPP FFA. Acid oxides $\mathrm{SiO}_{2}$ and $\mathrm{Al}_{2} \mathrm{O}_{3}$, occurring mainly in the glassy phase, show high reactivity in an alkaline environment $[10,42]$. Due to such properties, construction GPBM products can be formed on the basis of the Catalagzi TPP FFA and the Isken TPP FFA. However, comparing both FFAs, the Isken TPP FFA had a higher content of silica + alumina $(80.16 \%$ and $83.74 \%$ in the Catalagzi and Isken TPP FFAs, respectively). Bearing in mind that the geopolymer material became increasingly elastic with the increasing total $\mathrm{SiO}_{2}$ content in the raw materials, and a compressive strength increases along with the $\mathrm{Si} / \mathrm{Al}$ ratio [13,21], higher potential of Isken TPP FFA for the geopolymerization process was expected. The ratio of $\mathrm{SiO}_{2} / \mathrm{Al}_{2} \mathrm{O}_{3}$ was 2.07 and 
2.90. Therefore, geopolymerization could be favored in forming a poly(silate-siloxo) (-Si$\mathrm{O}-\mathrm{Al}-\mathrm{O}-\mathrm{Si}-\mathrm{O}-$ ) structure in which the $\mathrm{Si} / \mathrm{Al}$ ratio is 2 and a poly(silate-disiloxo) (-Si-O-Al$\mathrm{O}-\mathrm{Si}-\mathrm{O}-\mathrm{Si}-\mathrm{O}$ ) structure in which the $\mathrm{Si} / \mathrm{Al}$ ratio is 3, rather than poly(silate) (-Si-O-Al-O-) in which the $\mathrm{Si} / \mathrm{Al}$ ratio is 1 [21]. The $\mathrm{CaO}$ amount was less than $10 \%$ in both FFAs; however, the amount of $\mathrm{CaO}$ together with $\mathrm{MgO}$ was higher in the Catalagzi TPP FFA than Isken TPP FFA. The impact of calcium on the geopolymer is usually positive; a composite system with geopolymer gel and calcium-silicate-hydrate gel can coexist when the calcium content increases. Therefore, the final geopolymer properties may be the complementary result of both factors - the total content of $\mathrm{Si}$ and $\mathrm{Al}$ components but also the modifying effect of $\mathrm{CaO}$ [21]. FFAs can be classified as; (i) silica-aluminum, (ii) alumina-silica, (iii) calcium sulphate, and (iv) calcium types [43,44]. According to the results, both FFAs can be defined as an alumina-silica type. The FFA classification according to the ASTM C618 standard distinguishes the FFA class F or C. Basically, F class is silica ash obtained from the combustion of bituminous coal (hard and/or brown coal). Class $\mathrm{C}$ ashes are rich in calcium oxide and result from the combustion of sub-bituminous coals and lignite (brown coal). Additionally, $\mathrm{F}$ class FAs are characterized by the sum of $\mathrm{SiO}_{2}+\mathrm{Al}_{2} \mathrm{O}_{3}+\mathrm{Fe}_{2} \mathrm{O}_{3}$ components higher than $70 \%$, while for class C FAs this ratio is higher than 50 (by weight) (ASTM C618) [45]. The chemical composition of both the Catalagzi and Isken TPP FFAs confirmed the classification as the $\mathrm{F}$ type FAs.

Table 2. Chemical composition of oxides (\%) and loss on ignition (LOI, \%) determined for the Catalagzi and Isken TPP FFAs.

\begin{tabular}{ccccccccccc}
\hline FFA Type & $\mathrm{SiO}_{\mathbf{2}}$ & $\mathrm{Al}_{\mathbf{2}} \mathbf{O}_{\mathbf{3}}$ & $\mathbf{F e}_{\mathbf{2}} \mathrm{O}_{\mathbf{3}}$ & $\mathbf{C a O}$ & $\mathbf{N a}_{\mathbf{2}} \mathbf{O}$ & $\mathbf{M g O}$ & $\mathbf{K}_{\mathbf{2}} \mathbf{O}$ & $\mathbf{S O}_{3}$ & Other Oxides & $\mathbf{L O I}$ \\
\hline Catalagzi TPP & 54.08 & 26.08 & 6.68 & 2.00 & 0.79 & 2.67 & 4.53 & 0.73 & 2.44 & 1.52 \\
Isken TPP & 62.28 & 21.46 & 7.01 & 1.53 & 0.26 & 2.37 & 3.81 & 0.07 & 1.21 & 1.78 \\
\hline
\end{tabular}

LOI (\%), an indicator of residual carbon content, is a critical parameter when evaluating the effectiveness of the geopolymerization process. LOI values were determined as $1.52 \%$ and $1.78 \%$ for the Catalagzi TPP FFA and Isken TPP FFA, respectively (Table 2). Although obtained LOI values are common (e.g., [21,46]), it is worth noticing that the residual carbon from an inefficient coal combustion process in the power plant can absorb water and chemical admixtures. Further, it results in a change of air-void system in the geopolymer, negatively affects production of building materials, and reduces their frost resistance. The LOI values obtained for the Catalagzi and Isken TPP FFAs were relatively low, confirming that the Catalagzi and Isken TPP FFAs were suitable raw materials for the high-efficiency geopolymerization and GPBM production.

Different chemical composition was related to a variance in particle morphology of the Catalagzi TPP FFA and the Isken TPP FFA (Figure 2a,b). Generally, the particle morphology of both FFAs (Figure 2) indicated that they came from conventional dust furnaces, in which the temperature ranged from 1200 to $1600^{\circ} \mathrm{C}$, and finely ground coal was used. The high temperature of combustion created a spherical shape of particles and a glassy phase. The particles of FFA with spherical morphology are beneficial in order to achieve a successful polymerization process as they improve the rheological properties of the paste, increasing its workability [21]. Both FFAs had spherical particles (Figure 2a,b). However, more random particle geometry, rough and porous surface texture, and tendency to form agglomerates intermixed with the glassy phase were found for the Catalagzi TPP FFA. In contrast, a fraction of individual, almost perfectly spherical balls, clearly separated from the glassy phase, was observed for the Isken TPP FFA. Both FFAs had particles with a maximum size of $500 \mu \mathrm{m}$; however, the particle frequency of the Isken TPP FFA with a size smaller than $100 \mu \mathrm{m}$ was twice as high when compared to the Catalagzi TPP FFA (Figure 2c). The phenomenon is attributable to the greater surface area available for chemical reactions. The smaller particles have a larger surface area in comparison to the volume and thus, higher 
reactivity, including the rate of dissolution of the monomers, i.e., silicate and aluminate, consequently resulting in a more effective geopolymerization process [21].
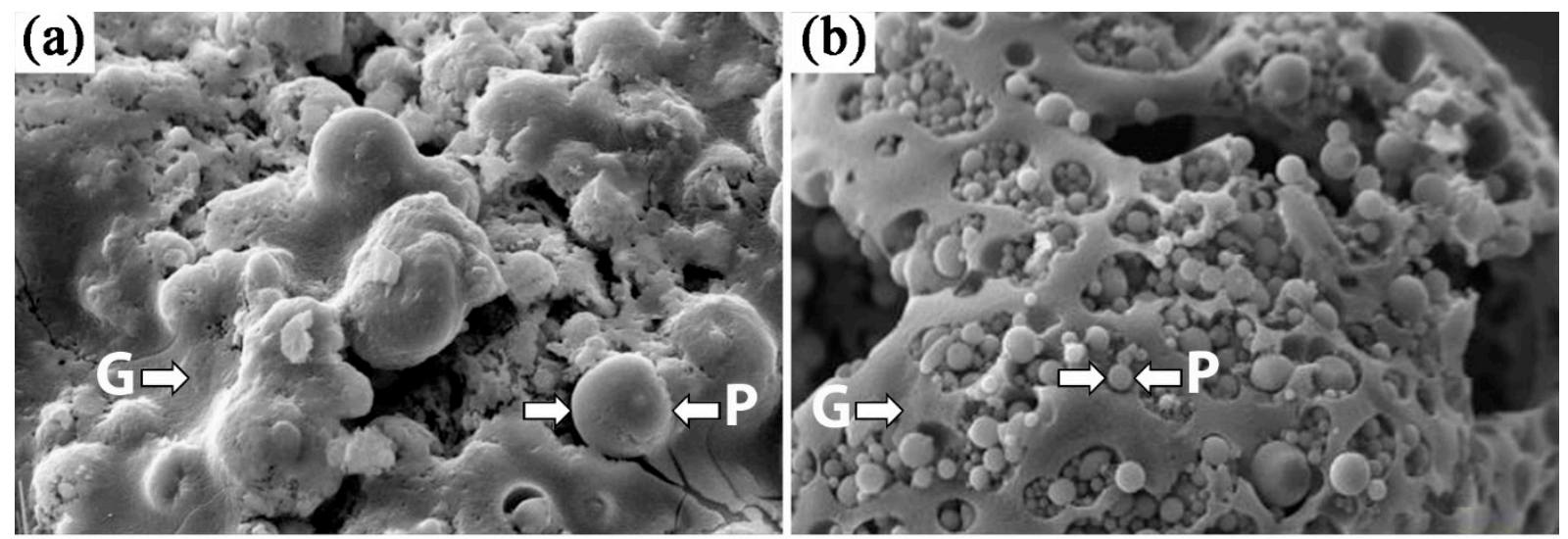

(c)

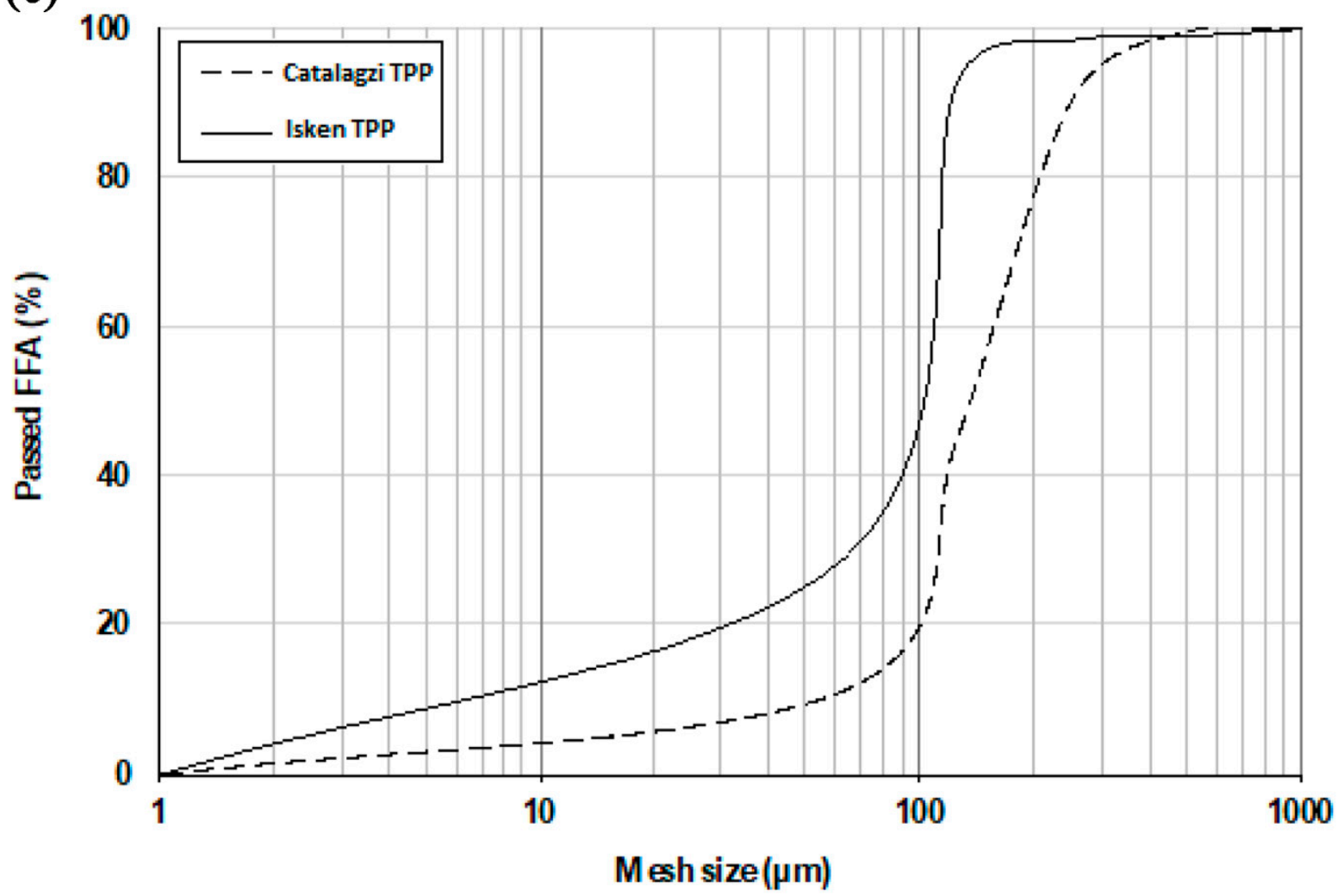

Figure 2. Morphology of (a) the Catalagzi TPP FFA, (b) the Isken TPP FFA, and (c) particle distribution.

Differences in particle morphology were confirmed by physical properties, i.e., the specific surface area of FFAs. BET values were determined as 1.11 for the Catalagzi TPP FFA, and two-fold higher values of $2.26 \mathrm{~m}^{2} \mathrm{~g}^{-1}$ were measured for Isken TPP FA (Table 3). The mean specific gravity of coal ashes was around 2.0. The values were standard; however, a variation between Catalagzi TPP FFA and Isken TPP FFA was resulted from a combination of several factors, such as particle shape, distribution, and chemical composition [47]. Along with a decrease in the size of particles, the density of the geopolymer increased. Indeed, in all cases higher values of air- and oven-dried and loose and tight bulk density (Table 3) were calculated for the Isken TPP FFA than Catalagzi TPP FFA; the smaller particles of Isken TPP FFA filled space in a more compact way. 
Table 3. Physical properties of the Catalagzi and Isken TPP FFAs.

\begin{tabular}{ccc}
\hline Properties & Catalagzi TPP FFA & Isken TPP FFA \\
\hline BET $\left(\mathrm{m}^{2} \mathrm{~g}^{-1}\right)$ & 1.11 & 2.26 \\
Specific gravity & 2.04 & 2.25 \\
Air-dried loose bulk density $\left(\mathrm{g} \mathrm{cm}^{-3}\right)$ & 0.87 & 1.10 \\
Air-dried tight bulk density $\left(\mathrm{g} \mathrm{cm}^{-3}\right)$ & 1.04 & 1.14 \\
Oven-dried loose bulk density $\left(\mathrm{g} \mathrm{cm}^{-3}\right)$ & 0.75 & 0.98 \\
Oven-dried tight bulk density $\left(\mathrm{g} \mathrm{cm}^{-3}\right)$ & 0.88 & 1.05 \\
\hline
\end{tabular}

The raw materials consisted of the RILEM Cembureau standard sand (Table 4) which complies with the TS EN 196-1 specification [48]. FFA and standard sand are two different materials. Indeed, the RILEM Cembureau standard sand has a specific gravity of 2.56 and density of $1.35 \mathrm{~kg} \mathrm{dm}^{-3}$ which are significantly higher than those measured for FFAs. Therefore, an addition of sand can decrease the total surface area of granular ingredients affecting the water demand and paste workability, hydration rates, and strength of geopolymers.

Table 4. The RILEM Cembureau standard sand (the left panel) and its properties (table).

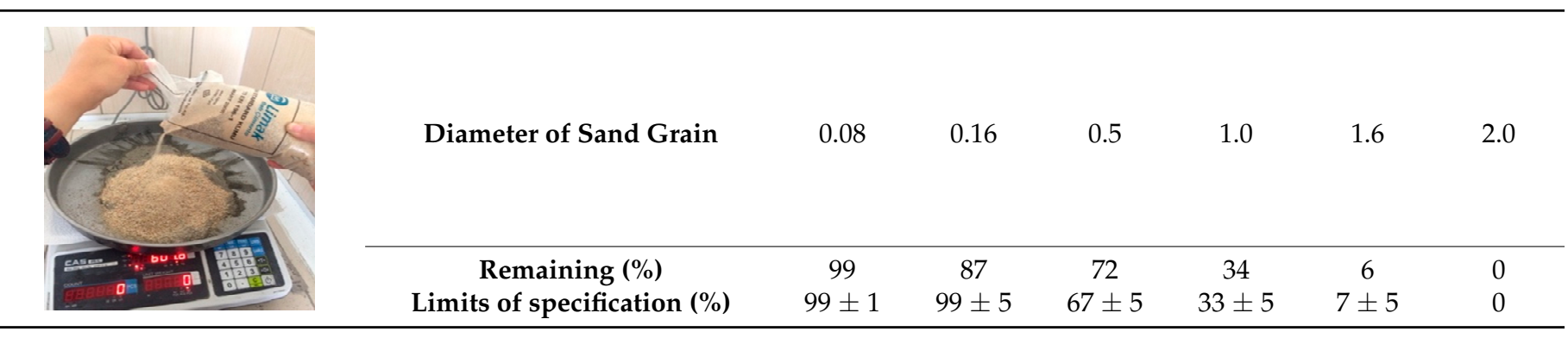

Considering the chemical and physical properties, the construction GPBM products can be formed on the basis of the Catalagzi TPP FFA and the Isken TPP FFA as well as with the addition of the RILEM Cembureau standard sand.

\subsection{GPBMs Production and Properties}

In this study, FFAs were activated through grinding, heating, and then alkali solutions. To produce the GPBM samples, different methods of sample preparation were compared. Sequentially added ingredients required double mixing with a total time of almost $12 \mathrm{~min}$. In the first step, paste consisting of FFA and $\mathrm{NaOH}$ was relatively viscous. Liquid $\mathrm{Na}_{2} \mathrm{SiO}_{3}$ was added in the second step. Another protocol consisted of FFA, $\mathrm{NaOH}$, and $\mathrm{Na}_{2} \mathrm{SiO}_{3}$ mixing for $1 \mathrm{~min}$ to obtain homozygous mortar. It was previously shown that length of mixing period and mortar viscosity affect geopolymer setting time [21]. The water in the mixing phase determines the workability of the paste during the production of the geopolymer. However, water evaporating from the geopolymer during the curing process creates discontinuous nanovoids. Therefore, with a shorter setting time (when the lower amount of free liquid is present) and improved homogeneity of mortar, a lower number of voids can occur, and higher compressive strength of the geopolymer can be achieved. Indeed, a "normal" mixing procedure resulted in a geopolymer product with a higher strength compared to the geopolymer produced by the separate mixing method. Therefore, a normal mixing procedure was preferred in further studies. On the other hand, discontinuous nanovoids were present also in materials prepared according to the "normal" mixing protocol and resulted in lightweight GPBMs with a density below $2 \mathrm{~g} \mathrm{~cm}^{-3}$.

Furthermore, FFA type, activator ratio $\left(\mathrm{NaOH}\right.$ and $/$ or $\left.\mathrm{Na}_{2} \mathrm{SiO}_{3}\right)$, and curing temperature were the key factors modifying geopolymer porosity (Table 5). For the Catalagzi TPP FFA produced at higher curing temperature $\left(100^{\circ} \mathrm{C}\right)$, the GPBM densities were generally 
lower. In the case of the activator ratio, a higher $\mathrm{NaOH}$ content vs. $\mathrm{Na}_{2} \mathrm{SiO}_{3}$ content and lower geopolymer porosity were observed. The lower porosity correlated with lower water absorption of the final GPBM products.

Table 5. The material characteristic (density, porosity), mechanical (flexural and compressive strength), and physical (water absorption, radiation absorption) properties of the GPBMs produced based on FFAs supplied from the Catalagzi and Isken TPPs and alkali activators ( $\mathrm{NaOH}$ and/or $\mathrm{Na}_{2} \mathrm{SiO}_{3}$ ) in different ratios.

\begin{tabular}{|c|c|c|c|c|c|c|c|c|c|}
\hline \multirow[b]{2}{*}{ 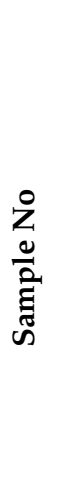 } & \multicolumn{3}{|c|}{ Mixing Ratio of Raw Materials } & \multicolumn{6}{|c|}{ GPBM Properties } \\
\hline & 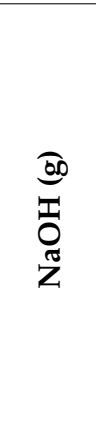 & 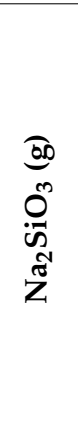 & 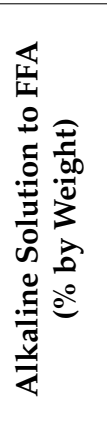 & 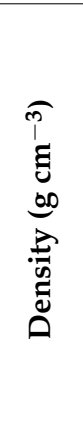 & $\begin{array}{c}\widehat{o} \\
\substack{0 \\
0 \\
0 \\
0 \\
0}\end{array}$ & 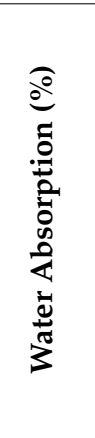 & 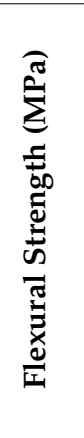 & 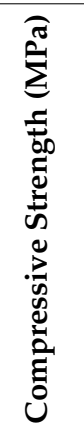 & 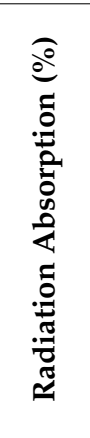 \\
\hline \multicolumn{10}{|c|}{ GPBMs produced from Catalagzi TPP FFA } \\
\hline \multicolumn{10}{|c|}{ Curing temperature $70^{\circ} \mathrm{C}$} \\
\hline 1 & 300 & - & $15^{*}$ & 1.46 & 30.20 & 22.30 & 5.3 & 30.3 & 3.00 \\
\hline 2 & 160 & 320 & 20 & 1.84 & 28.94 & 17.98 & 6.1 & 33.5 & 12.36 \\
\hline 3 & 120 & 120 & 10 & 1.69 & 23.65 & 14.81 & 7.8 & 39.0 & 2.56 \\
\hline 4 & 80 & 160 & 10 & 1.79 & 25.42 & 16.38 & 8.7 & 47.3 & 2.12 \\
\hline 5 & 134 & 266 & $20^{*}$ & 1.46 & 21.91 & 15.63 & 4.6 & 53.0 & 2.38 \\
\hline \multicolumn{10}{|c|}{ Curing temperature $100^{\circ} \mathrm{C}$} \\
\hline 6 & 96 & 144 & 10 & 1.56 & 25.23 & 16.56 & 8.2 & 34.2 & 2.56 \\
\hline 7 & 80 & 160 & 10 & 1.53 & 20.45 & 13.29 & 8.9 & 40.8 & 2.20 \\
\hline 8 & 160 & 320 & 20 & 1.58 & 25.23 & 16.56 & 3.9 & 46.1 & 3.88 \\
\hline 9 & 500 & - & $25^{*}$ & 1.45 & 31.23 & 23.75 & 3.9 & 47.0 & 2.03 \\
\hline 10 & 160 & 240 & $20^{*}$ & 1.24 & 23.40 & 17.50 & 3.0 & 47.5 & 3.53 \\
\hline 11 & 114 & 286 & $20^{*}$ & 1.32 & 22.80 & 17.46 & 8.8 & 49.0 & 5.21 \\
\hline \multicolumn{10}{|c|}{ GPBMs produced from Isken TPP FFA } \\
\hline \multicolumn{10}{|c|}{ Curing temperature $70^{\circ} \mathrm{C}$} \\
\hline 12 & 174 & 346 & 20 & 1.94 & 28.94 & 17.98 & 13.1 & 46.9 & 0.88 \\
\hline 13 & 500 & - & $25^{*}$ & 1.69 & 28.85 & 18.34 & 1.50 & 47.0 & 3.35 \\
\hline 14 & 330 & - & $15^{*}$ & 1.81 & 26.69 & 16.46 & 7.35 & 63.5 & 5.91 \\
\hline 15 & 125 & 315 & $20^{*}$ & 1.84 & 23.83 & 14.80 & 6.90 & 66.6 & 7.24 \\
\hline 16 & 130 & 130 & 10 & 2.00 & 26.84 & 17.55 & 13.4 & 71.4 & 5.21 \\
\hline 17 & 80 & 160 & 10 & 2.04 & 18.92 & 9.94 & 18.3 & 81.4 & 4.24 \\
\hline \multicolumn{10}{|c|}{ Curing temperature $100^{\circ} \mathrm{C}$} \\
\hline 18 & 110 & 110 & $10^{*}$ & 1.67 & 25.64 & 16.57 & 6.1 & 37.1 & 6.71 \\
\hline 19 & 148 & 372 & 20 & 1.98 & 16.16 & 10.07 & 4.2 & 46.6 & 0.61 \\
\hline 20 & 177 & 351 & 20 & 1.97 & 17.94 & 9.72 & 13.3 & 49.6 & 4.85 \\
\hline 21 & 330 & - & $15^{*}$ & 1.69 & 23.09 & 14.45 & 16.2 & 52.4 & 4.68 \\
\hline 22 & 125 & 315 & $20^{*}$ & 1.70 & 19.91 & 12.39 & 3.0 & 57.3 & 12.54 \\
\hline 23 & 87 & 173 & 10 & 1.95 & 20.88 & 13.24 & 6.8 & 60.1 & 2.12 \\
\hline 24 & 106 & 158 & 10 & 1.92 & 16.48 & 8.44 & 16.7 & 65.5 & 10.15 \\
\hline 25 & 264 & - & 10 & 2.01 & 13.94 & 7.09 & 16.5 & 93.3 & 4.77 \\
\hline
\end{tabular}


Generally, the raw material reactivity was controlled by numerous intrinsic (e.g., the mineralogical, chemical, structural composition, amount of reactive fraction of $\mathrm{SiO}_{2}$ and $\mathrm{Al}_{2} \mathrm{O}_{3}$ ) and extrinsic parameters (e.g., FA fineness level, type and proportion of raw materials, the ratio of activators, duration and temperature of the process) (Figure 1, Tables 2, 3 and 5), which consequently affected GPBM mechanical properties and homogeneity (Table 5). It is well known that a greater fineness level of the FFA increases paste workability and the rate of geopolymerization, shortens setting time, and improves physical (density), mechanical (compressive and flexural strength), and microstructural (compact and uniform matrix) properties of the geopolymer [21,44]. The mechanism of improving the physical and mechanical properties of GPBM is also attributed to a higher amount of alkaline aluminosilicate gel [21,49-52]. Accordingly, the better mechanical properties of the geopolymer were obtained when the Isken TPP FFA was used as raw material (Figure 2, Tables 2 and 3). Flexural strength, also known as modulus of rupture, or bending strength, or transverse rupture strength, is a material property defined as the stress in a material just before it yields in a flexure test. The flexural strength was dependent only on FFA type, and higher values were found for the GPBM samples prepared from the Isken TPP FFA (Table 5). The compressive strength test is a mechanical test measuring the maximum amount of compressive load a material can bear before fracturing. Compressive strength is the most used criterion in engineering applications because is of vital importance for the structural integrity of building materials in both the construction phase and after the construction is completed $[53,54]$. In this study, GPBMs with the best compressive strength values ( $>30 \mathrm{MPa}$; the GPBMs presented in Table 5) were selected among 169 produced materials, and similarly, as in the case of flexural strength, GPBMs produced from the Isken TPP FFA had higher compressive strength values. The range of compressive strength was in agreement with earlier studies [55]; however, it is worth noting that lower activator concentration $\left(\mathrm{Na}_{2} \mathrm{SiO}_{3} / \mathrm{NaOH}=2,10 \%\right)$ and lower curing temperature $\left(70{ }^{\circ} \mathrm{C}\right)$ caused an increase in compressive strength of GPBMs, in comparison to a higher temperature $\left(100{ }^{\circ} \mathrm{C}\right)$. The opposite effect was found for the higher amount of activator $\left(\mathrm{Na}_{2} \mathrm{SiO}_{3} / \mathrm{NaOH}=2\right.$, i.e., $20 \%)$; a decrease in the curing temperature $\left(70^{\circ} \mathrm{C}\right)$ caused a decrease in compressive strength of GPBMs.

Radiation causes serious harm to the environment and humans; thus, effective shielding from radiation sources should be provided. Even though the determination of the RA is important, there is a limited number of studies concerning this parameter in GPBM. In this study, the RA test was performed in a newly designed LRS cage according to the ASTM and TS EN standards. The RA of conventional OPC was $9.52 \%$, while GPBMs produced in different combinations of ingredients, mixing ratios, and curing temperatures had higher RA percentage values (Table 5). The highest RA of $12.54 \%$ was found for GPBMs produced from the Isken TPP FFA by activation with $\mathrm{Na}_{2} \mathrm{SiO}_{3} / \mathrm{NaOH}$ at a ratio of 2.5 and concentration of $20 \%$ (Table 5, sample number 22). Generally, the GPBMs produced from the Catalagzi TPP FFA had lower RA values; among them, the highest RA values were measured in alkali activator ratio of $2.0\left(\mathrm{Na}_{2} \mathrm{SiO}_{3}\right.$ to $\left.\mathrm{NaOH}\right)$ and its concentration was $20 \%$ (Table 5, sample number 2). Taking into account that: (1) geopolymers have good (or better) mechanical and chemical characteristics such as compressive strength, resistance to high temperature, acid resistance, and capacity to immobilize toxic elements (when compared to OPC) $[28,56,57]$; (2) GPBMs with the highest RA capacity also had a high density, flexural strength, compressive strength, and less porosity (Table 5); and (3) GPBMs produced from the Isken TPP FFA had higher RA and, at the same time, better mechanical and physical parameters than GPBMs produced from Catalagzi TPP FFA (Table 5), GPBMs proved suitable as an alternative material for a barrier against radiation. However, the properties which are suitable for providing the production process are optimized based on precise chemical analysis of the raw material, establishment of appropriate alkaline activators, and temperature of the process. Particularly, optimization should include the impact of these factors on structural continuity/porosity of the final product. It is an important issue in the context of direct functionality of geopolymer barriers as well as in the case of degradation 
in geopolymer material over time or in a dose-dependent manner. Little is known about the geopolymer performance under radiation; however, some studies suggest that direct changes in the pore structure due to radiation were found to be minimal. However, dose rate effect was observed in case of $\mathrm{H}_{2}$ generation from water by the transfer of absorbed energy from the solid geopolymer to the pore water $[28,58]$. Thus, the additive effect of changes in air-water status of geopolymer material and changes in the temperature of the external environment should be taken into account.

\subsection{Optimization Methods, Curve Fitting, and Mathematical Modeling}

Bearing in mind the importance of factors described above, such as chemical composition of the raw materials, ratio of ingredients, and curing temperature, it is necessary to have a tool that enables the selection of individual parameters and results in maximum RA values for geopolymer barriers against radiation. Mathematical modeling and appropriate algorithms can provide this without the need for costly experimentation.

Deviations during experiments are inevitable, but extreme deviations of individual measurement points should be eliminated. The least-squares method overcomes the deviation in experimental data. This technique results in a fitted curve. In order to find an optimally fitted curve, the data points and fitted curve can be denoted by $\left(x_{i}, y_{i}\right)$ and $q\left(x_{i}\right)$ $(i=1,2,3 \ldots n)$. The $\mathrm{i}^{\text {th }}$ point error $\varepsilon_{i}$ which gives the difference between $y_{i}$ and $q\left(x_{i}\right)(i=1$, $2,3 \ldots n)$ can be described by the following equation:

$$
\varepsilon_{i}=y_{i}-q\left(x_{i}\right)
$$

If $q\left(x_{i}\right)$ is defined as the polynomial function, the total error can be expressed as follows:

$$
\begin{gathered}
\sum_{i}^{N} \varepsilon_{i}=\sum_{i}^{N}\left(y_{i}-q\left(x_{i}\right)\right) \\
\sum_{i}^{N} \varepsilon_{i}=\sum_{i}^{N}\left(y_{i}-\left(\alpha_{0}+\alpha_{1} x_{i}+\alpha_{2} x_{i}^{2}+\cdots+\alpha_{n} x_{i}^{n}\right)\right)
\end{gathered}
$$

In order to obtain an optimally fitted curve for the data set, the square of the total error for points $E$ should be at a minimum, and this can be described as:

$$
E=\sum_{i}^{N}\left(\varepsilon_{i}\right)^{2}=\sum_{i}^{N}\left(y_{i}-\left(\alpha_{0}+\alpha_{1} x_{i}+\alpha_{2} x_{i}^{2}+\cdots+\alpha_{n} x_{i}^{n}\right)\right)^{2}
$$

Therefore, each partial derivative for each indefinite coefficient of $E$ needs to be zero, and this can be expressed as:

$$
\begin{gathered}
\frac{\partial E}{\partial \alpha_{0}}=0=-2 \sum_{i}^{n}\left(y_{i}-\left(\alpha_{0}+\alpha_{1} x_{i}+\alpha_{2} x_{i}^{2}+\cdots+\alpha_{n} x_{i}^{n}\right)\right) \\
\frac{\partial E}{\partial \alpha_{1}}=0=-2 \sum_{i}^{n}\left(y_{i}-\left(\alpha_{0}+\alpha_{1} x_{i}+\alpha_{2} x_{i}^{2}+\cdots+\alpha_{n} x_{i}^{n}\right)\right) x_{i} \\
\frac{\partial E}{\partial \alpha_{n}}=0=-2 \sum_{i}^{n}\left(y_{i}-\left(\alpha_{0}+\alpha_{1} x_{i}+\alpha_{2} x_{i}^{2}+\cdots+\alpha_{n} x_{i}^{n}\right)\right) x_{i}^{n}
\end{gathered}
$$

If the equalities above are arranged for an $n$th degree curve, the $(n+1)$ th particle, the curve, and undefined coefficients can be calculated [59] with the equation as given below:

$$
\sum_{n=1}^{n} q\left(x_{i}\right) \cdot \frac{\partial q\left(x_{i}\right)}{\partial \alpha_{k}}=\sum_{n=1}^{n} y_{i} \cdot \frac{\partial q\left(x_{i}\right)}{\partial \alpha_{k}}
$$

The basis of equations in this study is related to the working principle of the leastsquares fit method considering linear combinations of functions of the variables derived from experimental data. The importance of the mathematical model is to facilitate the prediction of RA \% without the need for experiments. Furthermore, due to the optimization of the mathematical model, a mixture design with a maximum RA \% was obtained. 
Numerical algorithms for optimization of nonlinear constraint can be divided into two methods, namely the gradient-based method and direct search method. Whereas the gradient-based optimization method depends on the first and second derivatives, the direct search method does not use the derivatives. The convergence of the direct search method is slower than the convergence of the gradient-based method, but the former method is more robust and has higher tolerance to noise in the objective function and constraints. In this study, two different numerical direct search methods were used, namely the simulated annealing (SA) and the differential evolution (DE) algorithms [60].

The SA algorithm is a random optimization method and simple stochastic function minimizer. The method is based on the terminology and genesis of the annealing process, i.e., a feature related to the temperature variation to be embedded in the operational characteristics of the algorithm. Using optimization terminology, annealing allows the structure to escape from a local minimum, explore, and settle on a minimum. Due to the annealing procedure, the optimum point avoids the local point and allows the global optimum of a given function to be approximated. The objective function in the DE method is defined under equality or inequality constraints. In the first step, the initial population determined with the target vector and donor vector is created by a mutation. To define the test vector for the new generation, the target vector and donor vectors are compared with the purpose of choosing the lower one. Therefore, if the test vector is lower than the target vector, the optimization algorithm is finished, else the procedure returns to the mutation step to produce a new generation.

Considering the results of the experiments (Table 5), optimum curves were fitted as multivariable polynomials functions for RA (\%). The curves were fitted to polynomial functions, using the command "Fit" in the Wolfram Mathematica 11 program. As a result of the curve fitting method based on the least-squares method, the equations 12 to 15 were derived using the data set from Table 5. RA was described by the following equations:

for GPBMs produced from the Catalagzi TPP FFA at $70{ }^{\circ} \mathrm{C}$

$$
\begin{aligned}
& \mathrm{RA}(\%)=\left(6.06681 \times 10^{-13}\right) a^{5}+\left(1.912 \times 10^{-10}\right) a^{4}+\left(5.96302 \times 10^{-8}\right) a^{3}+\left(1.677 \times 10^{-5}\right) a^{2}+ \\
& \left(3.0725 \times 10^{-3}\right) a+\left(9.97403 \times 10^{-13}\right) b^{5}-\left(1.32288 \times 10^{-15}\right) c^{5}-\left(1.85411 \times 10^{-15}\right) d^{5}+ \\
& \left(2.70814 \times 10^{-10}\right) b^{4}-\left(1.17738 \times 10^{-12}\right) c^{4}-\left(4.49614 \times 10^{-13}\right) d^{4}+\left(6.81304 \times 10^{-8}\right) b^{3}- \\
& \left(9.42366 \times 10^{-10}\right) c^{3}+\left(5.55359 \times 10^{-10}\right) d^{3}+\left(1.45796 \times 10^{-5}\right) b^{2}-\left(5.88341 \times 10^{-7}\right) c^{2}+ \\
& \left(1.14292 \times 10^{-6}\right) d^{2}+\left(1.88691 \times 10^{-3}\right) b-\left(1.57535 \times 10^{-4}\right) c+\left(1.33691 \times 10^{-3}\right) d+1.24475 \times 10^{-1} \\
& \text { for GPBMs produced from the Catalagzi TPP FFA at } 100{ }^{\circ} \mathrm{C} \\
& \mathrm{RA}(\%)=8.87011 \times 10^{-1}-\left(1.47085 \times 10^{-2}\right) a-\left(1.39286 \times 10^{-5}\right) a^{2}+\left(5.91645 \times 10^{-9}\right) a^{3} \\
& +\left(4.20831 \times 10^{-11}\right) a^{4}+\left(1.07088 \times 10^{-13}\right) a^{5}-\left(2.64208 \times 10^{-3}\right) b-\left(6.1538 \times 10^{-6}\right) b^{2} \\
& +\left(1.18374 \times 10^{-8}\right) b^{3}+\left(1.28551 \times 10^{-10}\right) b^{4}+\left(5.33933 \times 10^{-13}\right) b^{5}+\left(1.14801 \times 10^{-3}\right) c \\
& +\left(1.12699 \times 10^{-6}\right) c^{2}+\left(1.05019 \times 10^{-9}\right) c^{3}+\left(9.8909 \times 10^{-13}\right) c^{4}+\left(9.48881 \times 10^{-16}\right) c^{5} \\
& +\left(9.94322 \times 10^{-4}\right) d+\left(1.05721 \times 10^{-6}\right) d^{2}+\left(1.0887 \times 10^{-9}\right) d^{3}+\left(1.10331 \times 10^{-12}\right) d^{4} \\
& +\left(1.11359 \times 10^{-15}\right) d^{5}
\end{aligned}
$$

for GPBMs produced from the Isken TPP FFA at $70{ }^{\circ} \mathrm{C}$

$$
\begin{gathered}
\text { RA }(\%)=11.16+0.00582 a+\left(3.06 \times 10^{-11}\right) \times a^{2}-1.6288 \times 10^{-8} a^{3}-8.1628 \times 10^{-11} a^{4} \\
-2.8616 \times 10^{-13} a^{5}+0.002 b-4.7641 \times 10^{-7} b^{2}-5.76532 \times 10^{-9} b^{3} \\
-1.53343 \times 10^{-11} b^{4}-3.273 \times 10^{-14} b^{5}+0.00133 c+0.0000012 c^{2}+1.00626 \times 10^{-9} c^{3} \\
+8.668211 \times 10^{-13} c^{4}+7.734 \times 10^{-16} c^{5}+0.00189 d+0.00000140+4.8688 \times 10^{-10} d^{3} \\
-8.2528 \times 10^{-13} d^{4}-2.516434 \times 10^{-15} d^{5}
\end{gathered}
$$

for GPBMs produced from the Isken TPP FFA at $100{ }^{\circ} \mathrm{C}$ 


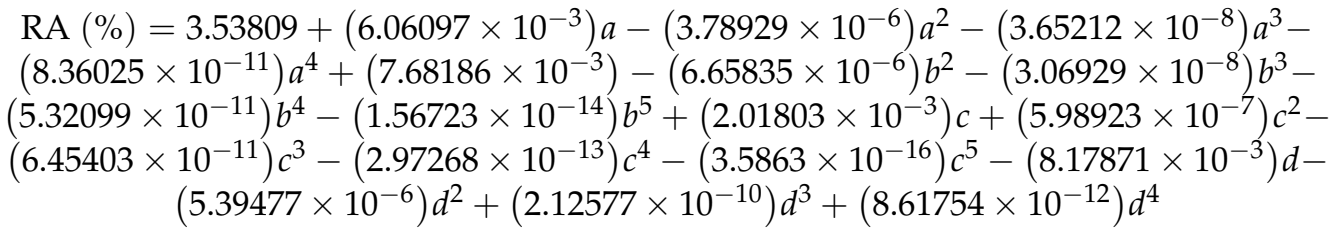

In the above equations, $\mathrm{a}, \mathrm{b}, \mathrm{c}$, and $\mathrm{d}$ are quantities of $\mathrm{NaOH}(\mathrm{g}), \mathrm{Na}_{2} \mathrm{SiO}_{3}(\mathrm{~g}), \mathrm{FFAs}(\mathrm{g})$, and RILEM Cembureau sand (g), respectively. By calculating the optimum of mixture ingredients, the equations presented above were maximized to find the maximum of the RA. The SA and DE algorithms were applied separately considering upper and lower bounds expressed as follows:

$$
\begin{gathered}
0 \leq \mathrm{a} \leq 400 \mathrm{~g} \\
0 \leq \mathrm{b} \leq 400 \mathrm{~g} \\
0 \leq \mathrm{c} \leq 1000 \mathrm{~g} \\
0 \leq \mathrm{d} \leq 800 \mathrm{~g} \\
0 \leq \mathrm{a}+\mathrm{b} \leq 500 \mathrm{~g} \\
0 \leq \mathrm{c}+\mathrm{d} \leq 1200 \mathrm{~g}
\end{gathered}
$$

The constraints of optimization in Equations (16)-(21) were obtained considering the maximum value of raw materials presented in Table 5. However, the amount of ingredients higher than this resulting from maximum values were chosen as upper constraints of optimization. Value 0 was fixed as the lower limit.

Figure $3 a-h$ depict the process of RA optimization with respect to design step numbers by using the SA and DE methods. The figures show how RA converges to a maximum during the optimization. The results are presented for the GPBMs produced from the Catalagzi and Isken TPP FFAs cured at 70 and $100{ }^{\circ} \mathrm{C}$.

After the optimization process for GPBMs produced from the Catalagzi and Isken TPP FFAs at $70{ }^{\circ} \mathrm{C}$ (CTPP-70 and ITPP-70) and $100{ }^{\circ} \mathrm{C}$ (CTPP-100 and ITPP-100), the unknown

\begin{tabular}{|c|c|c|c|c|c|c|}
\hline Optimization Method * & GPBMs & $\mathrm{N}_{\mathrm{a}} \mathrm{OH}(\mathrm{g})$ & $\mathrm{Na}_{2} \mathrm{SiO}_{3}(\mathrm{~g})$ & FFA (g) & Standard Sand (g) & RA (\%) \\
\hline \multirow{4}{*}{ 岕嘼 } & $\mathrm{GPBM}_{\mathrm{CTPP}-70}$ & 0 & 400 & 1000 & 200 & 70.7 \\
\hline & GPBM $_{\text {CTPP-100 }}$ & 0 & 400 & 1000 & 200 & 13.9 \\
\hline & GPBM $_{\text {ITPP-70 }}$ & 202 & 222 & 1000 & 200 & 8.0 \\
\hline & GPBM $_{\text {ITPP-100 }}$ & 169 & 194 & 1000 & 200 & 7.0 \\
\hline
\end{tabular}
coefficient of the predicted polynomial functions and optimum value of the RA \% were calculated as presented in Table 6 .

Table 6. Optimum values of the ingredients and calculated RA (\%) for different GPBMs produced from the Catalagzi and Isken TPP FFAs at curing temperature $70{ }^{\circ} \mathrm{C}\left(\mathrm{GPBM}_{\mathrm{CTPP}-70}\right.$ and $\left.\mathrm{GPBM}_{\mathrm{ITPP}-70}\right)$ and $100{ }^{\circ} \mathrm{C}\left(\mathrm{GPBM}_{\mathrm{CTPP}-100}\right.$ and $\left.\mathrm{GPBM}_{\mathrm{ITPP}-100}\right)$ with respect to SA and DE algorithm.

* Both methods (SA and DE) gave the same results.

The setting of ingredients for the production of GPBM based on the Catalagzi and Isken TPP FFAs and curing temperatures of 70 and $100{ }^{\circ} \mathrm{C}$ is shown in three dimensions and contour plots in Figure 4. They were calculated according to the maximum point and the variation of RA with respect to $\mathrm{Na}_{2} \mathrm{SiO}_{3}$ and FFA. The red circle points in Figure 4 showed variation and maximum RA (\%). With an increasing amount of the Catalagzi TPP FFA in GPBM cured at $70{ }^{\circ} \mathrm{C}$, an increase in RA was calculated at each amount of $\mathrm{Na}_{2} \mathrm{SiO}_{3}$ (Figure $4 \mathrm{a}, \mathrm{b}$ ). After the minimum point, the $\mathrm{Na}_{2} \mathrm{SiO}_{3}$ quantity caused a rise in RA. In the case of the GPBMs produced from the Catalagzi TPP FFA at $100{ }^{\circ} \mathrm{C}$, the RA increased along with the increase in FFA and $\mathrm{Na}_{2} \mathrm{SiO}_{3}$ quantities (Figure 4c,d). For GPBMs produced from the Isken TPP FFA at $70{ }^{\circ} \mathrm{C}$, an increase in FFA amount resulted in higher RA, while an 
increase in $\mathrm{Na}_{2} \mathrm{SiO}_{3}$ quantity led to RA decrease (Figure 4e,f). RA for the GPBMs produced from the Isken TPP FFA at $100{ }^{\circ} \mathrm{C}$ depended on defined quantities of FFA and $\mathrm{Na}_{2} \mathrm{SiO}_{3}$. Their improvement led to a rise in RA (Figure $4 \mathrm{~g}, \mathrm{~h}$ ). However, after the maximum point, the quantity of these variables caused a decrease in RA.

(a)

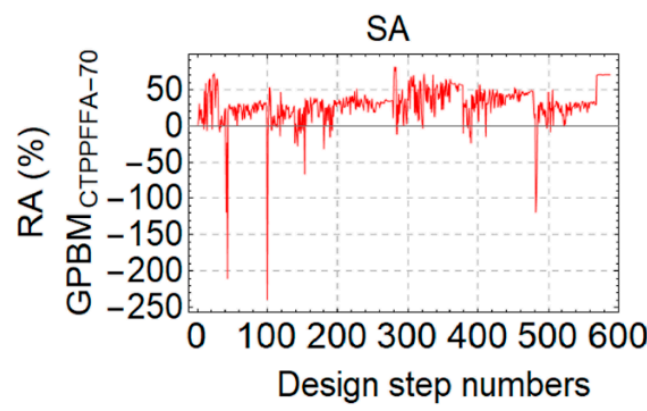

(c)

$\mathrm{SA}$

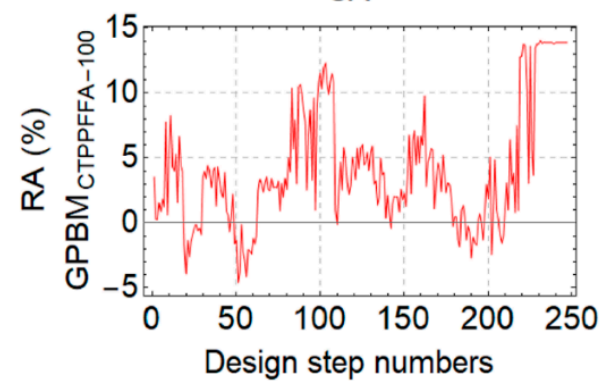

(e)

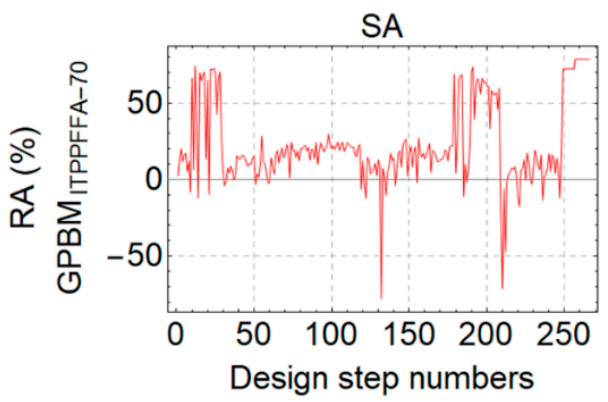

(g)

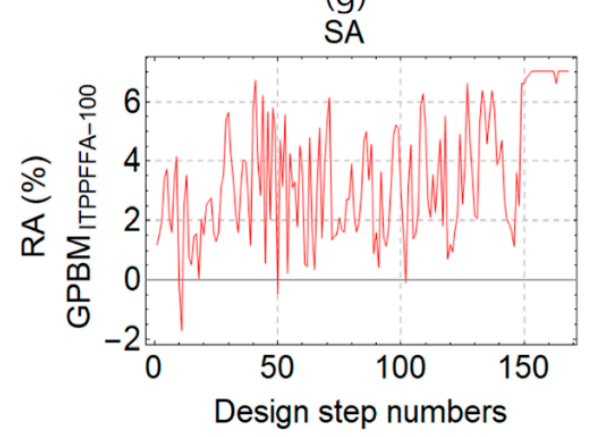

(b)

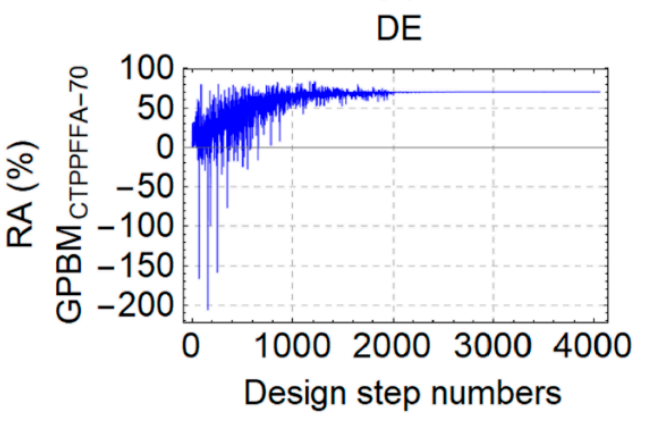

(d)

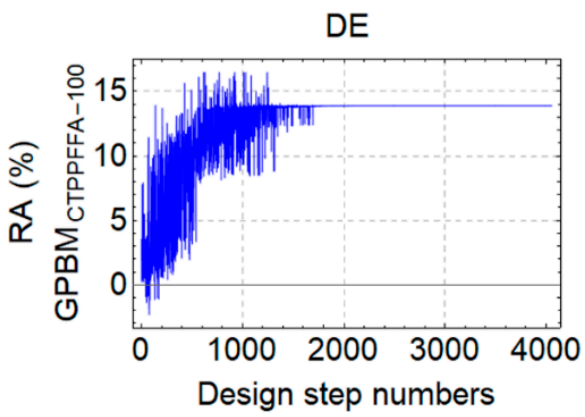

(f)

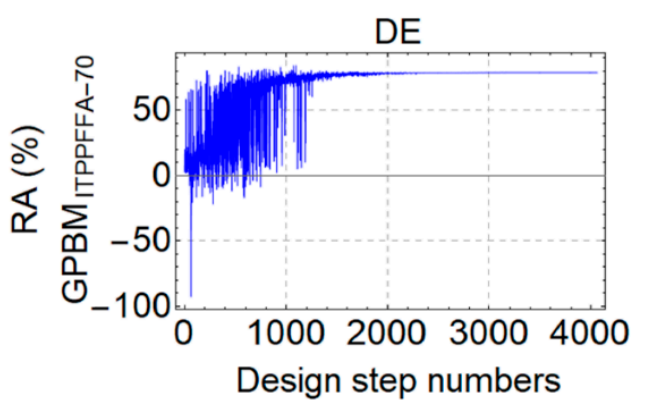

(h)

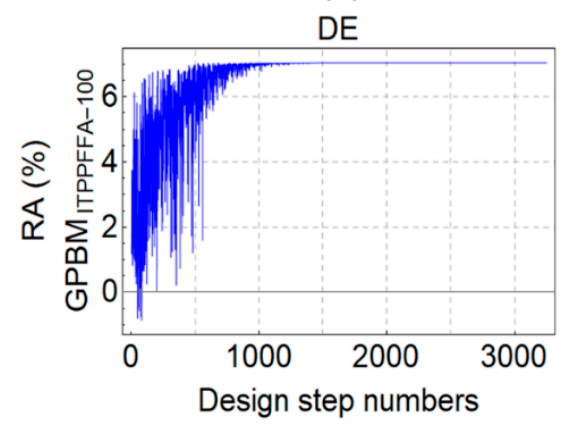

Figure 3. The process of radiation absorption (RA, \%) optimization with respect to design step numbers by using the simulated annealing (SA), and the differential evolution (DE) methods. GPBMs were produced from the Catalagzi TPP FFAs and cured at temperatures of $(\mathbf{a}, \mathbf{b}) 70{ }^{\circ} \mathrm{C}\left(\mathrm{GPBM}_{\mathrm{CTPPFFA}-70}\right)$ and (c,d) $100{ }^{\circ} \mathrm{C}\left(\mathrm{GPBM}_{\mathrm{CTPPFFA}-100}\right)$, as well as GPBM produced from the Isken TPP FFAs and cured at temperatures of $(\mathbf{e}, \mathbf{f}) 70^{\circ} \mathrm{C}\left(\mathrm{GPBM}_{\text {ITPPFFA-100 }}\right)$ and $(\mathbf{g}, \mathbf{h}) 100^{\circ} \mathrm{C}\left(\mathrm{GPBM}_{\text {ITPPFFA-100 }}\right)$. 
(a)

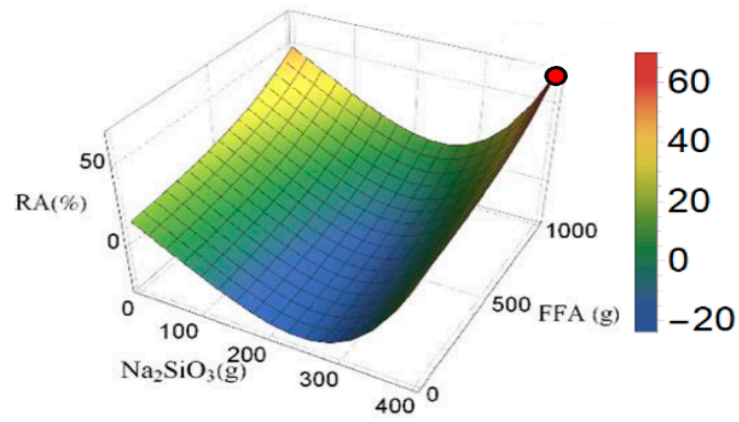

(c)

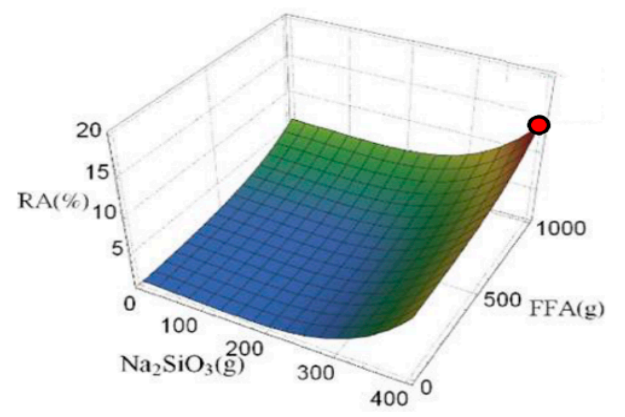

(e)

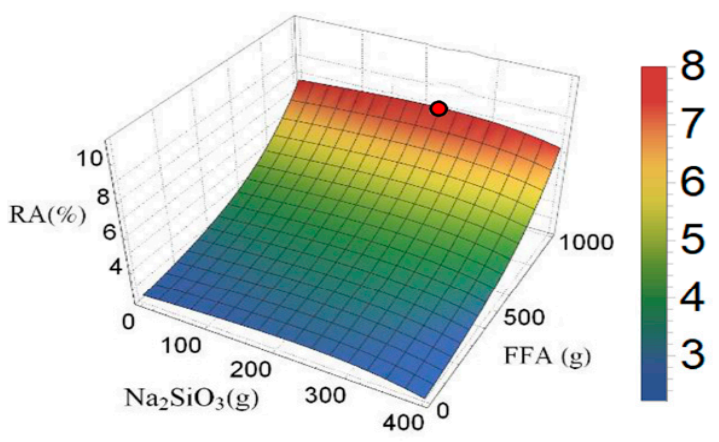

(g)

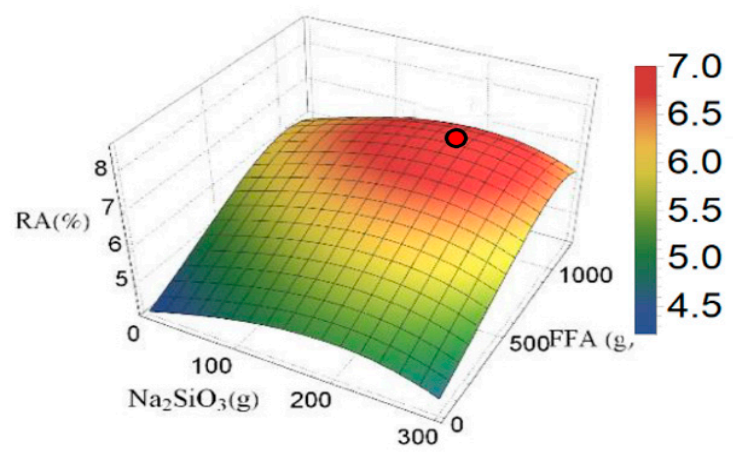

GPBM $_{\text {СTPPFFA-70 }}$ (b)

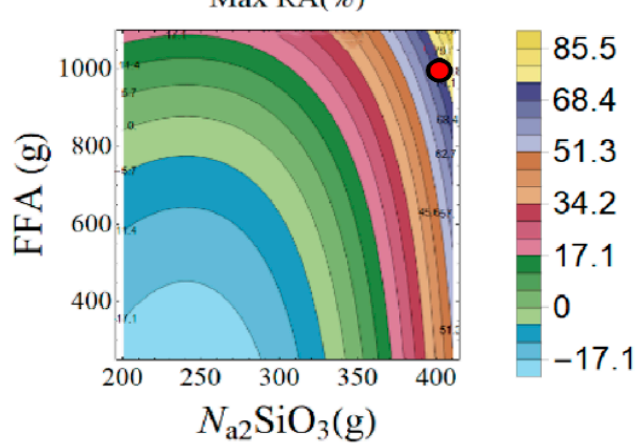

GPBM $_{\text {CTPPFFA-100 }} \quad \stackrel{(d)}{\text { Max RA(\%) }}$

12.5 10.0

7.5

5.0

2.5

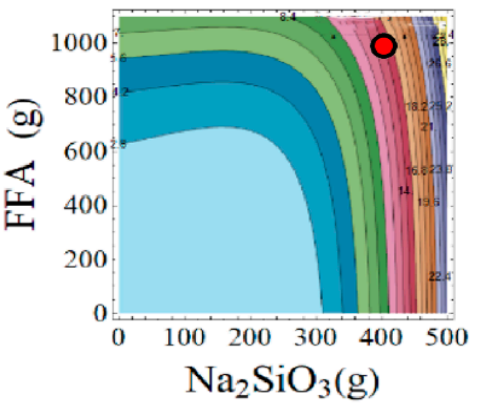

$\because 29.4$

26.6

23.8

21.0

18.2

15.4

12.6

9.8

7.0

4.2

(f)

GPBM $_{\text {ITPPITA-70 }}$

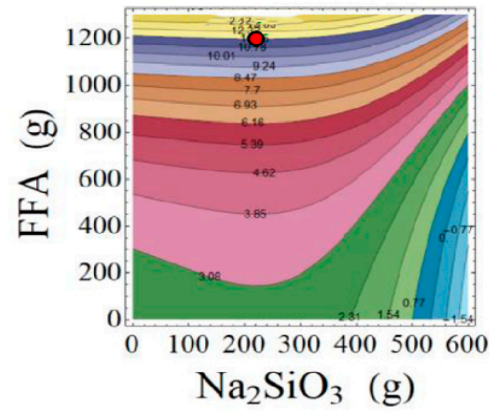

13.0

11.5

10.0

8.4

6.9

5.3

3.8

2.3

0.7

$-0.7$

(h)

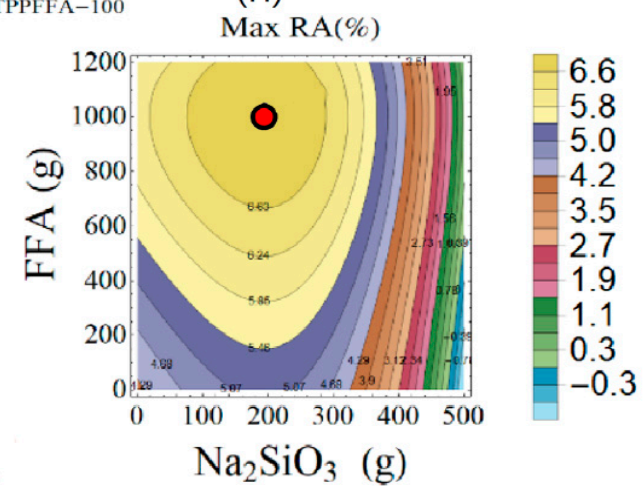

Figure 4. Variation of radiation absorption (RA, \%) in three dimensions and contour plot graph with respect to $\mathrm{Na}_{2} \mathrm{SiO}_{3}$ and FFA quantities for GPBM produced from the Catalagzi TPP FFA at curing temperatures of $(\mathbf{a}, \mathbf{b}) 70{ }^{\circ} \mathrm{C}\left(\mathrm{GPBM}_{\mathrm{CTPPFFA}-70}\right)$, (c, d) $100{ }^{\circ} \mathrm{C}\left(\mathrm{GPBM}_{\mathrm{CTPPFF}}-100\right)$; and GPBM produced from the Isken TPP FFA at curing temperatures of $(\mathbf{e}, \mathbf{f}) 70^{\circ} \mathrm{C}\left(\mathrm{GPBM}_{\mathrm{ITPPFF}}-70\right),(\mathrm{g}, \mathrm{h}) 100{ }^{\circ} \mathrm{C}$ $\left(\mathrm{GPBM}_{\mathrm{ITPPFFA}-100}\right)$. Red dots indicate the optimum points. 
According to the mathematical model developed in this study, the effect of FFAs supplied from different TPPs on RA is an important issue.

\section{Conclusions}

The suitable features of GPBMs produced from the Catalagzi and Isken TPP FFAs consist of (i) use of raw materials (FFAs) and chemical activators ( $\mathrm{NaOH}$ and / or $\mathrm{Na}_{2} \mathrm{SiO}_{3}$ ) instead of the cement, which accounts for a net reduction in energy use and greenhouse gas during the production; (ii) use of waste FFAs instead of the natural non-renewable sources; (iii) reuse of FFAs to reduce the storage of toxic waste; (iv) and increased life of building structures due to the improved material durability. With the above in mind and proving better engineering properties, we describe the developed GPBM material as an eco-geopolymer.

Using a newly designed measurement system consisting of the LRS cage, GPBMs were shown to have an excellent potential to serve as a barrier against harmful radiation. Mathematical modeling with the least-squares method was used to fit a polynomial function to quantities of FFAs, sand, $\mathrm{NaOH}$, and $\mathrm{Na}_{2} \mathrm{~S}_{\mathrm{i}} \mathrm{O}_{3}$ and as a result find their optimum to achieve the maximum RA.

The detailed conclusions include:

(1) FFAs with total aggregate content of $70-80 \%, 12 \mathrm{M} \mathrm{NaOH}$, the $\mathrm{Na}_{2} \mathrm{SiO}_{3} / \mathrm{NaOH}$ ratio of $1-2.5$, and $24 \mathrm{~h}$ of curing at 70 or $100{ }^{\circ} \mathrm{C}$ all represent the conditions for GPBM production that result in final materials with an average compressive strength of 40-44 and 58-63 MPa for the GPBM produced from the Catalagzi TPP and Isken TPP FFAs, respectively.

(2) Higher reactivity of the Isken TPP FFA, and thus better mechanical and physical properties of the geopolymer, resulted from finer particles and greater surface area of raw material. The highest compressive strength was measured as $93.3 \mathrm{MPa}$ for the GPBM produced with $10 \% \mathrm{NaOH}$ and cured at $100{ }^{\circ} \mathrm{C}$.

(3) The best GPBM (produced from the Isken TPP FFA) had the highest RA of $12.5 \%$, density of $1.70 \mathrm{~g} \mathrm{~cm}^{-3}$, porosity of $19.9 \%$, water absorption of $12.4 \%$, and compressive strength of $57.3 \mathrm{MPa}$; thus, eco-friendly GPBMs are lightweight construction materials with good mechanical properties.

(4) According to the mathematical model developed in this study, the effect of FFA/alkali activator type and quantity on RA is an important issue. Optimization is required to obtain maximum RA values. Mathematical modeling and appropriate algorithms can provide this without costly experimentation.

However, the performance of GPBMs under radiation must be deeply understood. Radiation can lead to a change in the microstructure of a material and related chemical, physical, and mechanical parameters; thus, the dependences require further studies. Predicting GPBM properties and methodology with mathematical models seems irreplaceable, particularly for production of sophisticated materials for special purposes. Attempts have been made to produce materials such as radiation shielding concrete (RSC) [61] and ambient-cured heavyweight geopolymer concrete (HWGC) [62] to protect from the sources that emit harmful radiation in the medical and nuclear industries, and lunar building materials which need to meet criteria of resistance to severe temperature cycles (102.4 to $387.1 \mathrm{~K})$, stability in a vacuum environment, minimal water requirements, and sourcing from local Moon materials [63].

Author Contributions: Conceptualization, N.D.-S.; Methodology, N.D.-S., A.B., S.E., V.B.; Software, H.Ç.; Validation, N.D.-S., A.B., S.E., V.B.; Formal Analysis, E.S., A.G.A., P.N.; Investigation, M.S.-H., M.H.; Resources, M.S.-H., M.H.; Data Curation, A.B., E.S., A.G.A., P.N., V.B., H.Ç.; Writing-Original Draft Preparation, N.D.-S.; Writing-Review and Editing, N.D.-S., M.S.-H., M.H.; Visualization, N.D.-S., A.B., V.B., H.Ç.; Supervision, N.D.-S.; Project Administration, N.D.-S.; Funding Acquisition, M.S.-H., M.H. All authors have read and agreed to the published version of the manuscript. 
Funding: The study is a part of the project "Development of eco-friendly composite materials based on geopolymer matrix and reinforced with waste fibers" funded by the European Commission, within the 7th Framework Programme for Research and Technology Development (FP7), Topic \#02: Waste management, recycling and urban mining (Project No. ELAC2015/T02-0721) under the ERANet-LAC: Latin America, Caribbean and European Union and supported by a grant of the Turkish Scientific and Technological Research Council of Turkey (TUBITAK). The Turkish project number is 116Y549. The RA part of this study is supported by TUBITAK 2209/B Programme, project grant no. 1139B411701722.

\section{Institutional Review Board Statement: Not applicable.}

Informed Consent Statement: Not applicable.

Data Availability Statement: No new data were created or analyzed in this study. Data sharing is not applicable to this article.

Acknowledgments: The authors would like to thank Betül Dikkaya for her support during this study. We acknowledge that the research study was carried out in the Waste Technologies Laboratory of Niğde Ömer Halisdemir University. We thank ÇIMSA, one of the leading companies of Turkish cement industry, which supports this study and Adnan Güven and Gökhan Arikoğlu, former and present managers of the ÇİMSA Niğde Plant. We also acknowledge Baki Öztürk and Fatih Erdurcan for improving the text.

Conflicts of Interest: The authors declare no conflict of interest.

\section{References}

1. Okoye, F.N.; Durgaprasad, J.; Singh, N.B. Effect of silica fume on the mechanical properties of fly ash based-geopolymer concrete. Ceram. Int. 2016, 42, 3000-3006. [CrossRef]

2. Korniejenko, K.; Łach, M.; Dogan-Saglamtımur, N.; Furtos, G.; Mikuła, J. The overview of mechanical properties of short natural fiber reinforced geopolymer composites. Environ. Res. Technol. 2020, 3, 28-39. [CrossRef]

3. Luhar, S.; Luhar, I. Fly ash based geopolymer mortar-strength performance. Int. J. Recent Technol. Eng. (IJRTE) 2020, 8, 1181-1186.

4. Szechyńska-Hebda, M.; Marczyk, J.; Ziejewska, C.; Hordyńska, N.; Mikuła, J.; Hebda, M. Neutral geopolymer foams reinforced with cellulose studied with the FT-Raman spectroscopy. IOP Conf. Ser. Mater. Sci. Eng. 2019, 706, 012017. [CrossRef]

5. Doğan-Sağlamtimur, N.; Bilgil, A.; Öztürk, B. Reusability of Ashes for the Building Sector to Strengthen the Sustainability of Waste Management. In Handbook of Research on Supply Chain Management for Sustainable Development; IGI Global Publishing: Hershey, PA, USA, 2018; Chapter 14; pp. 265-281. ISBN 9781522557579. [CrossRef]

6. Kurtoğlu, A.E.; Alzeebaree, R.; Aljumaili, O.; Niş, A.; Gülşan, M.E.; Humur, G.; Çevik, A. Mechanical and durability properties of fly ash and slag based geopolymer concrete. Adv. Concr. Constr. 2018, 6, 345-362. [CrossRef]

7. Huseien, G.F.; Mirza, J.; Ismail, M.; Ghoshal, S.K.; Hussein, A.A. Geopolymer mortars as sustainable repair material: A comprehensive review. Renew. Sust. Energ. Rev. 2017, 80, 54-74. [CrossRef]

8. Gado, R.A.; Hebda, M.; Łach, M.; Mikuła, J. Alkali Activation of Waste Clay Bricks: Influence of The Silica Modulus, $\mathrm{SiO}_{2} / \mathrm{Na}_{2} \mathrm{O}$, $\mathrm{H}_{2} \mathrm{O} / \mathrm{Na}_{2} \mathrm{O}$ Molar Ratio, and Liquid/Solid Ratio. Materials 2020, 13, 383. [CrossRef] [PubMed]

9. Ren, B.; Zhao, Y.; Bai, H.; Kang, S.; Zhang, T.; Song, S. Eco-friendly geopolymer prepared from solid wastes: A critical review. Chemosphere 2021, 267, 128900. [CrossRef]

10. Doğan-Sağlamtimur, N.; Bilgil, A.; Szechyńska-Hebda, M.; Parzych, S.; Hebda, M. Eco-Friendly Fired Brick Produced from Industrial Ash and Natural Clay: A Study of Waste Reuse. Materials 2021, 14, 877. [CrossRef] [PubMed]

11. Zhu, Y. Zheng, Z.; Deng, Y.; Shi, C.; Zhang, Z. Advances in immobilization of radionuclide wastes by alkali activated cement and related materials. Cem. Concr. Comp. 2022, 126, 104377. [CrossRef]

12. Asim, N.; Alghoul, M.; Mohammad, M.; Amin, M.H.; Akhtaruzzaman, M.; Amin, N.; Sopian, K. Emerging sustainable solutions for depollution: Geopolymers. Constr. Build. Mater. 2019, 199, 540-548. [CrossRef]

13. Szechyńska-Hebda, M.; Marczyk, J.; Ziejewska, C.; Hordyńska, N.; Mikuła, J.; Hebda, M. Optimal Design of pH-neutral Geopolymer Foams for Their Use in Ecological Plant Cultivation Systems. Materials 2019, 12, 2999. [CrossRef] [PubMed]

14. Davidovits, J. SPE PACTEC'79; Society of Plastic Engineers: Danbury, CT, USA, 1979.

15. Koumoto, T. Production of high compressive strength geopolymers considering fly ash or slag chemical composition. J. Mater. Civ. Eng. 2019, 31, 06019006. [CrossRef]

16. Djobo, J.N.Y.; Elimbi, A.; Tchakouté, H.K.; Kumar, S. Volcanic ash-based geopolymer cements/concretes: The current state of the art and perpectives. Environ. Sci. Pollut. Res. 2017, 24, 4433-4446. [CrossRef] [PubMed]

17. Öz, H.Ö.; Doğan-Sağlamtimur, N.; Bilgil, A.; Tamer, A.; Günaydın, K. Process Development of Fly Ash-Based Geopolymer Mortars in view of Mechanical Characteristics. Materials 2021, 14, 2935. [CrossRef] [PubMed]

18. Somna, K.; Jaturapitakkul, C.; Kajitvichyanukul, P.; Chindaprasirt, P. NaOH-activated ground fly ash geopolymer cured at ambient temperature. Fuel 2011, 90, 2118-2124. [CrossRef] 
19. Arnoult, M.; Perronnet, M.; Autef, A.; Rossignol, R. How to control the geopolymer setting time with the alkaline silicate solution. J. Non-Cryst Solids. 2018, 495, 59-66. [CrossRef]

20. Chindaprasirt, P.; De Silva, P.; Hanjitsuwan, S. Effect of high-speed mixing on properties of high calcium fly ash geopolymer paste. Arab. J. Sci. Eng. 2014, 39, 6001-6007. [CrossRef]

21. Marczyk, J.; Ziejewska, C.; Gądek, S.; Korniejenko, K.; Łach, M.; Góra, M.; Kurek, I.; Doğan-Sağlamtimur, N.; Hebda, M.; Szechyńska-Hebda, M. Hybrid Materials Based on Fly Ash, Metakaolin, and Cement for 3D Printing. Materials 2021, 14, 6874. [CrossRef]

22. Mohammed, K.S.; Azeez, A.B.; Al Bakri, A.M.M.; Hussin, K.; Rahmat, A.B. The effect of barite content on anti radiation properties of geopolymer fly ash concrete incorporated natural rock ores of hematite. Int. J. Sci. Res. 2014, 3, 1818-1827.

23. Aygün, B. Neutron and gamma radiation shielding properties of high-temperature-resistant heavy concretes including chromite and wolframite. J. Radiat. Res. Appl. Sci. 2019, 12, 352-359. [CrossRef]

24. Akkurt, I.; Akyıldırım, H.; Mavi, B.; Kılınçarslan, Ş.; Basyigit, C. The effect of pumice rate on the gamma absorption parameters of concrete. Acta Phys. Pol. A 2012, 121, 144-146. [CrossRef]

25. Adewuyi, Y.G. Recent Advances in Fly-Ash-Based Geopolymers: Potential on the Utilization for Sustainable Environmental Remediation. ACS Omega 2021, 6, 15532-15542. [CrossRef] [PubMed]

26. Cantarel, V.; Motooka, T.; Yamagishi, I. Geopolymers and Their Potential Applications in the Nuclear Waste Management Field-A Bibliographical Study-Japan Atomic Energy Agency; JAEA-Review 2017-014; International Atomic Energy Agency (IAEA): Vienna, Austria, 2017.

27. Jang, J.G.; Park, S.M.; Lee, H.K. Physical barrier effect of geopolymeric waste form on diffusivity of cesium and strontium. J. Hazard. Mater. 2016, 318, 339-346. [CrossRef] [PubMed]

28. Kim, B.; Lee, J.; Kang, J.; Um, W. Development of geopolymer waste form for immobilization of radioactive borate waste. J. Hazard. Mater. 2021, 419, 126402. [CrossRef]

29. Shalbi, S.M.; Jaafar, M.S.; Ahmed, N.M.; Al-Jarrah, A.M.; Naji, A.; Alsadig Ahmed, A.; Qaeed, M.A. Effect of fly ash geopolymer with $15 \%$ barium sulphate as a design shielding box on radiation attenuation using GafchramicXR-QA2 film dosimetry. IOSR $J$. Eng. (IOSRJEN) 2017, 7, 13-17. [CrossRef]

30. Kubissa, W.; Glinicki, M.A.; Dąbrowski, M. Permeability testing of radiation shielding concrete manufactured at industrial scale. Mater. Struct. 2018, 51, 83. [CrossRef]

31. Basyigit, C.; Uysal, V.; Kilincarslan, Ş.; Mavi, B.; Günoğlu, K.; Akkurt, I.; Akkaş, A. Investigating radiation shielding properties of different mineral origin heavyweight concretes. AIP Conf. Proc. 2011, 1400, 232-235. [CrossRef]

32. The International Atomic Energy Agency. The Behaviours of Cementitious Materials in Long Term Storage and Disposal of Radioactive Waste IAEA-TECDOC-1701; International Atomic Energy Agency (IAEA): Vienna, Austria, 2013.

33. Tamzok, N. Domestic Coal-based Thermal Power Plant. Potential, Constraints and Solutions, Thermal Power Plants in Turkey (Yerli Kömüre Dayalı Termik Santral Potansiyeli, Darboğazlar ve Çözüm Önerileri, Türkiye'de Termik Santraller); TMMOB Publication Number: Ankara, Turkey, 2017; pp. 135-142.

34. Özkan, A.; Turan, E.; Kaplan, B.M. Investigation of fly ash effect on rheological and filtration properties of drilling muds. Fresenius Environ. Bull. 2018, 27, 9189-9194.

35. TS EN 933-10 Tests for Geometrical Properties of Aggregates-Part 10: Assessment of Fines-Grading of Filler Aggregates (Air Jet Sieving), In Turkish Standards. Available online: https://standards.iteh.ai/catalog/standards/cen/cc9acb3e-3176-4461-8e2d6cb1dfc816e7/en-933-10-2009 (accessed on 8 January 2022).

36. Arıcı, E.; Çelik, E.; Keleştemur, O. An analysis of the engineering properties of mortars containing corn cob ash and polypropylene fiber using the Taguchi and Taguchi-based Grey Relational Analysis methods. Case Stud. Constr. Mater. 2021,15, e00652. [CrossRef]

37. ASTM C1437-15 Standard Test Method for Flow of Hydraulic Cement Mortar. In ASTM International. Available online: https:/ / www.astm.org/c1437-15.html (accessed on 8 January 2022).

38. TS EN 772-3 Methods of Test for Masonry Units-Part 3: Determination of Net Volume and Percentage of Voids of Clay Masonry Units by Hydrostatic Weighing; Türk Standardları Enstitüsü (Turkish Standards Institution): Ankara, Turkey. Available online: https: / / standards.iteh.ai/catalog/standards/cen/724fb5fe-662d-40cf-b5b1-cc348aa45ca6/en-772-3-1998 (accessed on 8 January 2022).

39. ASTM C348-14 Standard Test Method for Flexural Strength of Hydraulic-Cement Mortars. In ASTM International. Available online: https:/ / www.astm.org/c0348-14.html (accessed on 8 January 2022).

40. ASTM C349-14 Standard Test Method for Compressive Strength of Hydraulic-Cement Mortars (Using Portions of Prisms Broken in Flexure). In ASTM International. Available online: https:/ / www.astm.org/c0349-14.html (accessed on 8 January 2022).

41. TS EN 12390-3 Testing Hardened Concrete-Part 3: Compressive Strength of Test Specimens. Available online: http:/ / www.vota. com.tr/assets/ts-en-12390-3.pdf (accessed on 8 January 2022).

42. Diaz, E.I.; Allouche, E.N.; Eklund, S. Factors affecting the suitability of fly ash as source material for geopolymers. Fuel 2010, 89, 992-996. [CrossRef]

43. Valentim, B.V.; Hower, J.C. Influence of feed and sampling systems on element partitioning in Kentucky fly ash. Int J. Coal Geol. 2010, 82, 94-104. [CrossRef]

44. $\quad$ Łach, M.; Gado, R.A.; Marczyk, J.; Ziejewska, C.; Dogan-Saglamtimur, N.; Mikuła, J.; Szechyńska-Hebda, M.; Hebda, M. Process design for a production of sustainable materials from post-production clay. Materials 2021, 14, 953. [CrossRef] 
45. ASTM C618 Standard Specification for Coal Fly Ash and Raw or Calcined Natural Pozzolan for Use as a Mineral Admixture in Concrete, In ASTM International. Available online: https:/ / www.astm.org/c0618-00.html (accessed on 8 January 2022).

46. Osholana, T.S.; Dludlu, M.K.; Oboirien, B.; Sadiku, R. Enhanced reactivity of geopolymers produced from fluidized bed combustion bottom ash. S. Afr. J. Chem. Eng. 2020, 34, 72-77. [CrossRef]

47. Bhatt, A.; Priyadarshini, S.; Mohanakrishnan, A.A.; Abri, A.; Sattler, M.; Techapaphawit, S. Physical, chemical, and geotechnical properties of coal fly ash: A global review. Case Stud. Constr. Mater. 2019, 11, e00263. [CrossRef]

48. TS EN 196-1 Methods of Testing Cement-Part 1: Determination of Strength, In Turkish Standards. Available online: https:// standards.iteh.ai/catalog/standards/cen/37b8816e-4085-4dcc-a642-a383d9bddd6c/en-196-1-2016 (accessed on 8 January 2022).

49. Nath, S.K.; Kumar, S. Role of particle fineness on engineering properties and microstructure of fly ash derived geopolymer. Constr. Build. Mater. 2020, 233, 117294. [CrossRef]

50. Firdaus, Y.İ.; Daud, R. Contribution of fineness level of fly ash to the compressive strength of geopolymer mortar. MATEC Web Conf. 2017, 103, 01026. [CrossRef]

51. Jamkar, S.S.; Ghugal, Y.M.; Patankar, S.V. Effect of fineness of fly ash fineness on workability and compressive strength of geopolymer concrete. Indian Concr. J. 2013, 87, 57-61.

52. Cong, P.; Cheng, Y. Advances in geopolymer materials: A comprehensive review. J. Traffic Transp. Eng. 2021, 8, 283-314. [CrossRef]

53. Demirel, Y. An experimental purpose for correlation of data of rebound hammer as to axial load levels on the different strength of concrete columns. Düzce Üniversitesi Bilim ve Teknol. Dergisi. 2015, 3, 76-87.

54. Yalcin, M. Building Material/Application; Eskisehir, Turkey. 2021. Available online: https://insaat.eskisehir.edu.tr/muhsiny/ MLZ204/icerik/12H-2)\%20Beton\%20üretimi-taze\%20beton\%20deneyleri-2-1\%20(2020-2021).pdf (accessed on 8 January 2022). (In Turkish).

55. Mermerdaş, K.; Manguri, S.; Nassani, D.E.; Oleiwi, S.M. Effect of aggregate properties on the mechanical and absorption characteristics of geopolymer mortar. Eng. Sci. Technol. Int. J. 2017, 20, 1642-1652. [CrossRef]

56. Mierzwiński, D.; Łach, M.; Hebda, M.; Walter, J.; Szechyńska-Hebda, M.; Mikuła, J. Thermal phenomena of alkali-activated metakaolin studied with a negative temperature coefficient system. J. Therm Anal. Calorim. 2019, 138, 4167-4175. [CrossRef]

57. Korniejenko, K.; Figiela, B.; Miernik, K.; Ziejewska, C.; Marczyk, J.; Hebda, M.; Cheng, A.; Lin, W.-T. Mechanical and Fracture Properties of Long Fiber Reinforced Geopolymer Composites. Materials 2021, 14, 5183. [CrossRef]

58. Leay, L.; Potts, A.; Donoclift, T. Geopolymers from fly ash and their gamma irradiation. Mater. Lett. 2018, 227, 240-242. [CrossRef]

59. Uzun, I. Numerical Analysis (in Turkish); Beta Publishing: İstanbul, Turkey, 2011.

60. Champion, B.; Strzebonski, A. Constrained Optimization; Wolfram Mathematica Tutorial Collection: Champaign, IL, USA, 2008.

61. Tyagi, G.; Singhal, A.; Routroy, S.; Bhunia, D.; Lahoti, M. Radiation Shielding Concrete with alternate constituents: An approach to address multiple hazards. J. Hazard. Mater. 2021, 404, 124201. [CrossRef] [PubMed]

62. Wang, K.; Tang, Q.; Cui, X.; He, Y.; Liu, L. Development of near-zero water consumption cement materials via the geopolymerization of tektites and its implication for lunar construction. Sci. Rep.-UK 2016, 6, 29659.

63. Montes, C.; Broussard, K.; Gongre, M.; Simicevic, N.; Mejia, J.; Tham, J.; Allouche, E.; Davis, G. Evaluation of lunar regolith geopolymer binder as a radioactive shielding material for space exploration applications. Adv. Space Res. 2015, 56, 1212-1221. [CrossRef] 